\title{
NH3-SCR of NO with novel active, supported vanadium-containing Keggin-type heteropolyacid catalysts
}

Bukowski, Anna; Schill, Leonhard; Nielsen, David; Mossin, Susanne ; Riisager, Anders; Albert, Jakob

Published in:

Reaction Chemistry and Engineering

Link to article, DOI:

$10.1039 / \mathrm{d}$ Ore00033g

Publication date:

2020

Document Version

Peer reviewed version

Link back to DTU Orbit

Citation (APA):

Bukowski, A., Schill, L., Nielsen, D., Mossin, S., Riisager, A., \& Albert, J. (2020). NH - SCR of NO with novel active, supported vanadium-containing Keggin-type heteropolyacid catalysts. Reaction Chemistry and Engineering, 5, 935-948. https://doi.org/10.1039/d0re00033g

\section{General rights}

Copyright and moral rights for the publications made accessible in the public portal are retained by the authors and/or other copyright owners and it is a condition of accessing publications that users recognise and abide by the legal requirements associated with these rights.

- Users may download and print one copy of any publication from the public portal for the purpose of private study or research.

- You may not further distribute the material or use it for any profit-making activity or commercial gain

- You may freely distribute the URL identifying the publication in the public portal 


\title{
$\mathrm{NH}_{3}$-SCR of $\mathrm{NO}$ with novel active, supported vanadium-containling Keggin-type heteropolyacid catalysts
}

Anna Bukowski ${ }^{a}$, Leonhard Schill ${ }^{b}$, David Nielsen ${ }^{b}$, Susanne Mossin ${ }^{b}$, Anders Riisager ${ }^{b}$ and Jakob Alberta*

a Lehrstuhl für Chemische Reaktionstechnik, Friedrich-Alexander-Universität ErlangenNürnberg, Egerlandstr. 3, 91058 Erlangen, Germany;

b Technical University of Denmark, Department of Chemistry, Centre for Catalysis and Sustainable Chemistry, Kemitorvet, Building 207, 2800 Kgs. Lyngby, Denmark

*E-Mail: jakob.albert@fau.de

Contact details of the corresponding author:

Phone: (+49)-(0)9131-85-67417 Fax: (+49)-(0)9131-85-27421; e-mail: jakob.albert@fau.de

\begin{abstract}
Supported vanadium-substituted Keggin polyoxometalates (POMs) were applied as catalysts for the selective catalytic reduction of $\mathrm{NO}$ using $\mathrm{NH}_{3}$ as reductant $\left(\mathrm{NH}_{3}-\mathrm{SCR}\right)$. Interestingly, HPA-3 $\left(\mathrm{H}_{6} \mathrm{PV}_{3} \mathrm{Mo}_{9} \mathrm{O}_{40}\right)$ was found to be the most active catalytic species, and $\mathrm{TiO}_{2}$ (anatase) the most promoting support for the SCR reaction in the temperature range $200-350{ }^{\circ} \mathrm{C}$. Moreover, $10 \mathrm{wt} . \% \mathrm{HPA}-3$ loading was found to be optimum resulting in nearly complete $\mathrm{NO}$ conversion at $350{ }^{\circ} \mathrm{C}$. Characterization by several techniques, including $\mathrm{N}_{2}$-physisorption, $\mathrm{NH}_{3}$-TPD, FTIR, XPS and TEM showed distinctive structural HPA-3 support interactions explaining the beneficial interplay between both parts for the SCR reaction. Furthermore, different catalytically active surface species were identified at various reaction temperatures and SCR conditions by in-situ EPR spectroscopy. The study introduces a novel type of heterogeneous supported vanadium-based $\mathrm{NH}_{3}-\mathrm{SCR}$ catalysts comprising redox-active POMs, which so far mainly have been applied for homogeneously catalyzed reactions.
\end{abstract}

Keywords: DeNOx, selective catalytic reduction, polyoxometalates, EPR spectroscopy 
Thermal power plants are big emitters of harmful $\mathrm{NO}_{x}$ gases, which cause formation of acid rain $\left(\mathrm{HNO}_{3}\right)$, ground level ozone and photochemical smog that negatively affect ecosystems and human life. Despite the ever increasing cost competitiveness of fluctuating, renewable electricity sources like wind and solar ${ }^{1}$, some thermal power plant capacity is probably still needed due to insufficient storage capacity. ${ }^{2}$ Firing or co-firing of biomass can help to secure grid stability while causing little net- $\mathrm{CO}_{2}$ emissions ${ }^{3-7}$ and is on the rise in Europe ${ }^{8}$ and elsewhere. ${ }^{3,9}$

Selective catalytic reduction with ammonia $\left(\mathrm{NH}_{3}-\mathrm{SCR}\right)$ has been implemented successfully at stationary power plants since the 1980s, and is considered a mature technology with catalyst lifetimes typically between three to five years. ${ }^{10}$ The most widely used catalyst is $\mathrm{V}_{2} \mathrm{O}_{5}$ $\mathrm{WO}_{3} / \mathrm{TiO}_{2}$ (anatase) with $\mathrm{V}_{2} \mathrm{O}_{5}$ and $\mathrm{WO}_{3}$ loadings in the ranges of $1-5$ and $5-10$ wt.\%, respectively $\left(\mathrm{WO}_{3}\right.$ can be substituted by $\left.\mathrm{MoO}_{3}\right)$. Unlike in coal-fired plants, rapid catalyst deactivation is experienced in biomass-fired power plants. 11-14 The increased rate of deactivation is caused by the high content of alkali metals, especially potassium, in biomass. 15-16 Potassium-containing aerosols such as $\mathrm{K}_{2} \mathrm{SO}_{4}$ and $\mathrm{KCl}$ can penetrate the catalyst and react with its acid sites hampering adsorption of $\mathrm{NH}_{3}$ on the surface of the catalyst. This lowers the activity since this adsorption is a vital step in $\mathrm{NH}_{3}-\mathrm{SCR} .{ }^{17}$

Industrially proven method of cleaning $\mathrm{NO}_{x}$ from flue gases at biomass-fired plants are injection of fly ash rich in aluminosilicates ${ }^{18}$ and tail-end placement of the deNO ${ }_{x}$ unit. ${ }^{19}$ In the former case, potassium is removed from the flue gas by chemically binding to the aluminosilicates and in the latter case by the dust- and $\mathrm{SO}_{2}$ removal units. Both strategies reduce catalyst deactivation by lowering the concentration of potassium in the flue gas duct.

Strategies to make $\mathrm{NH}_{3}$-SCR catalysts inherently more potassium resistant have so far only been reported at the laboratory and pilot plant level and include coating with a basic, potassium repellent layer ${ }^{20-22}$ and increasing the number of acid sites on catalysts. Replacing $\mathrm{WO}_{3}$ or $\mathrm{MoO}_{3}$ with their respective Keggin-type heteropolyacids, $\mathrm{H}_{3} \mathrm{PW}_{12} \mathrm{O}_{40}$ or $\mathrm{H}_{3} \mathrm{PMo}_{12} \mathrm{O}_{40}$ has been reported to increase the number of acid sites and thereby the potassium tolerance at moderate loadings of $100 \mu \mathrm{mol} \mathrm{K} \mathrm{g}^{-1}$ catalyst ${ }^{23-24}$ Those Keggin-type heteropolyacids belong to the class of polyoxometalates (POMs), which are well-defined metal-oxyanions linked with oxygen bridges of early transition metals at their highest oxidation state (e.g. $\mathrm{Mo}^{\mathrm{VI}}, \mathrm{W}^{\mathrm{VI}}$ or $\left.\mathrm{VV}\right)$. The anions can also contain a multitude of heteroatoms to improve their chemical and thermal stability. ${ }^{25}$ POMs have attracted considerable attention due to their architectures and attractive physicochemical properties including strong Brønsted acidity, high proton mobility, fast multi-electron transfer, high solubility and resistance to hydrolytic and oxidative degradations. This multifunctionality has especially also prompted their use in various homogeneous and heterogeneous catalysis applications. ${ }^{26-27}$ For example, as highly selective homogeneous catalysts in lignocellulosic biomass oxidation to formic acid and as sustainable heterogeneous catalysts for esterification reactions between glycerol and acetic acid or methanol with oleic acid for biodiesel production. ${ }^{28-31}$

The above-mentioned Keggin-type heteropolyanions typically consist of a W- or Mo-based Keggin framework $\left[\mathrm{XMo}_{12} \mathrm{O}_{40}\right]^{\mathrm{n}-}$ or $\left[\mathrm{XW}_{12} \mathrm{O}_{40}\right]^{\mathrm{n}-}$ where vanadium polyoxoanions can be easily incorporated. ${ }^{32}$ Keggin-type molybdophosphoric acid allows the incorporation of up to six vanadium atoms resulting in structures described by " $\mathrm{H}_{3+n} \mathrm{PV}_{n} \mathrm{Mo}_{12-n} \mathrm{O}_{40}$ " with $\mathrm{n}$ being the degree of substitution, which are easy to prepare. ${ }^{33}$ According to their stoichiometry, they add 
more acid sites to the catalyst than the parent molybdophosphoric acid and further potassiumicle Online tolerance improvements in $\mathrm{NH}_{3}-\mathrm{SCR}$ might accordingly been expected. Furthermore, incorporation of $\mathrm{V}$ species into the Keggin structure might change their SCR activity compared to the $\mathrm{V}$ species present in the traditional $\mathrm{V}_{2} \mathrm{O}_{5}-\mathrm{WO}_{3} / \mathrm{TiO}_{2}$ catalyst. To the best of our knowledge, catalysts containing $\mathrm{H}_{3+n} \mathrm{PV}_{\mathrm{n}} \mathrm{Mo}_{12-\mathrm{n}} \mathrm{O}_{40}$ (with $\mathrm{n}>0$ ) have so far not been reported for the $\mathrm{NH}_{3}-\mathrm{SCR}$ reaction.

In the present study, we have investigated the catalytic performance of vanadium-containing Keggin-type polyoxometalates supported on anatase $\left(\mathrm{HPA}-\mathrm{n} / \mathrm{TiO} \mathrm{O}_{2}\right)$ for $\mathrm{NH}_{3}-\mathrm{SCR}$ in simulated flue gas, and characterized the prepared catalysts using analytical methods like TEM, XPS and in-situ EPR to obtain a detailed understanding of the SCR performance. Since only NO (and no $\mathrm{NO}_{2}$ ) was used as reactant the standard SCR reaction (eq. 1) was expected to take place during the experiments.

$$
4 \mathrm{NH}_{3}+4 \mathrm{NO}+\mathrm{O}_{2} \rightarrow 4 \mathrm{~N}_{2}+6 \mathrm{H}_{2} \mathrm{O}
$$

\section{Results and Discussion}

\section{Catalytic activity of HPA-n/TiO ${ }_{2}$ catalysts}

Initially, the catalytic activity of various vanadium-substituted Keggin-POMs with the general composition $\mathrm{H}_{3+\mathrm{x}} \mathrm{PV}_{\mathrm{n}} \mathrm{Mo}_{12-\mathrm{n}} \mathrm{O}_{40}$ (HPA-n with $\mathrm{n}=0-6$ ) supported on anatase $\left(\mathrm{TiO}_{2}\right)$ was investigated. All catalysts were prepared with a POM-loading of $15 \mathrm{wt} . \%$. Anatase was applied as a state-of-the-art support already well known for many SCR applications including diesel engines, diesel locomotives and automobiles. ${ }^{34-37}$ The supported POM catalysts were prepared by wet impregnation, dried and the elemental composition determined by ICP-OES (for details see Table S1 in the ESI).

Figure 1 shows the temperature-dependent NO conversion for the different supported HPA-n catalysts, and as expected NO conversion increased with higher reaction temperature for all the catalysts. The unsubstituted and the lowest vanadium-substituted supported POMs (HPA-0/TiO 2 and HPA-1/TiO ${ }_{2}$ ) showed the lowest activity in the performed SCR experiments, while the highest $\mathrm{NO}$ conversion, and thus SCR activity, was achieved with $\mathrm{HPA}-3 / \mathrm{TiO}_{2}$. Two competing effects can possibly explain this behaviour: On the one hand, a higher vanadium content in the POM structure leads to increased SCR activity, due to an increased redox activity provided by the vanadium centres. On the other hand, the thermal stability of the HPA-n structures decreases with increasing vanadium content. ${ }^{38}$ Moreover, it is reported that up to $180^{\circ} \mathrm{C}$ the crystal water free compounds are present. On raising the temperature up to $380^{\circ} \mathrm{C}$, the constitutional water is totally removed without destroying the Keggin structure for lowsubstituted HPA- $n$ with $n=1-3$. The influence of the latter effect on catalytic activity was evident for the six-fold substituted POM $\left(\mathrm{HPA}-6 / \mathrm{TiO}_{2}\right)$ which possessed the highest activity up to $280^{\circ} \mathrm{C}$, but was less active at higher temperatures due to thermal instability of the structure. ${ }^{39}$

The three-fold vanadium-substituted POM $\left(\mathrm{HPA}-3 / \mathrm{TiO}_{2}\right)$ catalyst had a good compromise regarding vanadium-content (and thus catalytic activity) and structural stability, resulting in nearly full $\mathrm{NO}$ conversion at $350^{\circ} \mathrm{C}$ and was selected for further studies. These results are well in line with previous findings showing comparable SCR performance of $\mathrm{V}_{2} \mathrm{O}_{5}-\mathrm{WO}_{3} / \mathrm{TiO}_{2}$ with higher vanadium contents. 40 


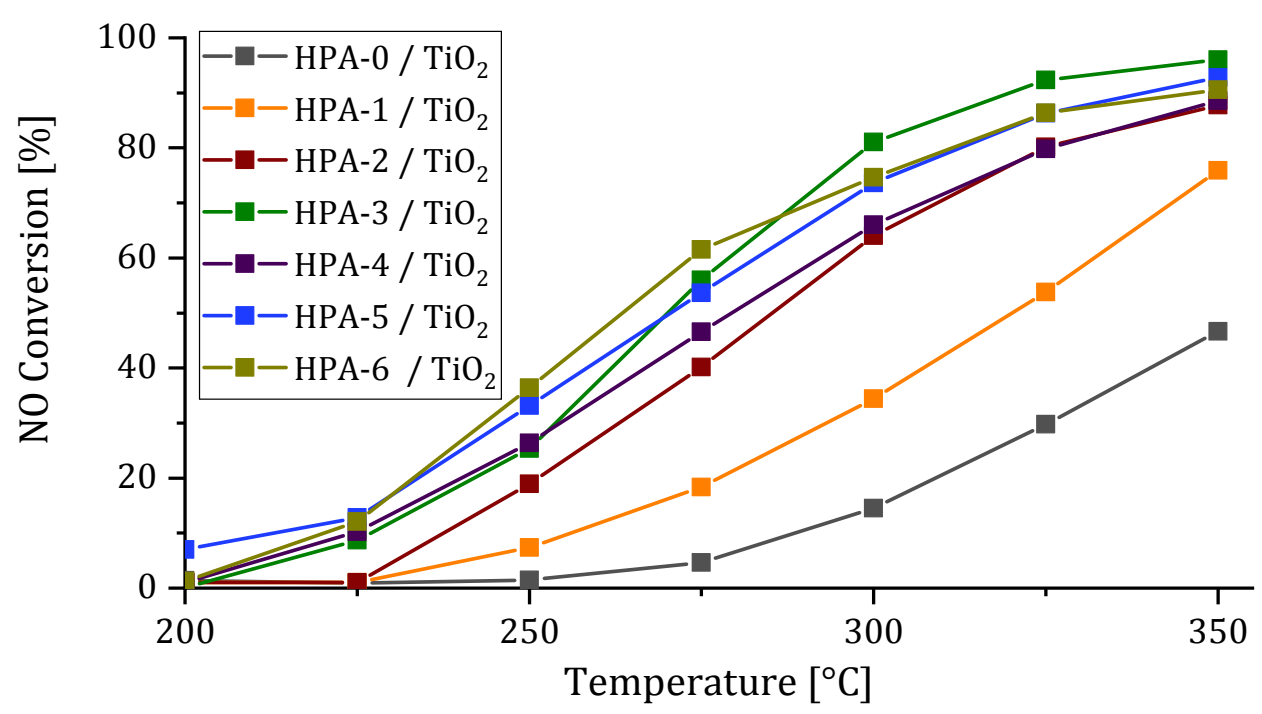

Figure 1: NO conversion versus temperature for different HPA-n/TiO $2(15$ wt. $\% \mathrm{HPA}-\mathrm{n}$ with $\mathrm{n}=0-6)$ catalysts in $\mathrm{NH}_{3}$-SCR. Reaction conditions: $50 \mathrm{mg}$ catalyst $(180-300 \mu \mathrm{m}), 300 \mathrm{mg}$ diluting agent $\left(\mathrm{SiO}_{2}\right), 1000 \mathrm{ppm} \mathrm{NO}$,

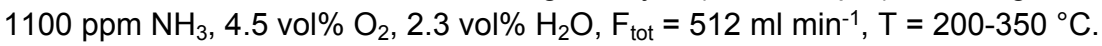

\section{Optimization of the POM loading on $\mathrm{HPA}-3 / \mathrm{TiO}_{2}$}

In the next set of experiments, the SCR activity of the preferred $\mathrm{HPA}-3 / \mathrm{TiO}_{2}$ catalyst was examined with different HPA-3 loadings of 7.5, 10, 15 and $20 \mathrm{wt} . \%$, and Figure 2 shows the activity profiles for the different catalysts. The catalyst with $7.5 \mathrm{wt} \%$ HPA-3 loading showed the lowest $\mathrm{NO}$ conversion up to $290^{\circ} \mathrm{C}$, where after its activity significantly increased in the temperature range from $290-350{ }^{\circ} \mathrm{C}$ reaching the performance of the $15 \mathrm{wt} . \%$ loaded catalyst at $350{ }^{\circ} \mathrm{C}$. Furthermore, the catalyst with 20 wt.\% HPA-3 loading showed the second lowest NO conversion up to $290{ }^{\circ} \mathrm{C}$, and the lowest activity at higher temperatures of all tested catalysts. Interestingly, the 10 and $15 \mathrm{wt}$ \% loaded catalysts performed very similar yielding the highest $\mathrm{NO}$ conversion and thus activity in the whole temperature range, suggesting that this loading range was optimum to reach monolayer coverage of HPA-3 on the $\mathrm{TiO}_{2}$ support and thereby full utilization of the catalytically active POM. Theoretical calculations based on the surface area of the used $\mathrm{TiO}_{2}$ support $\left(82.9 \mathrm{~m}^{2} \mathrm{~g}^{-1}\right.$, see ESI, Table S3) and an average POM-diameter of 13-14 $\AA 41$ confirm monolayer coverage at a POM-loading around $12-14$ wt.\%. However, further analysis is required to explain why $290{ }^{\circ} \mathrm{C}$ was a critical temperature for the $7.5 \mathrm{wt} . \%$ loaded $\mathrm{HPA}-3 / \mathrm{TiO}_{2}$ catalyst, as addressed below. 


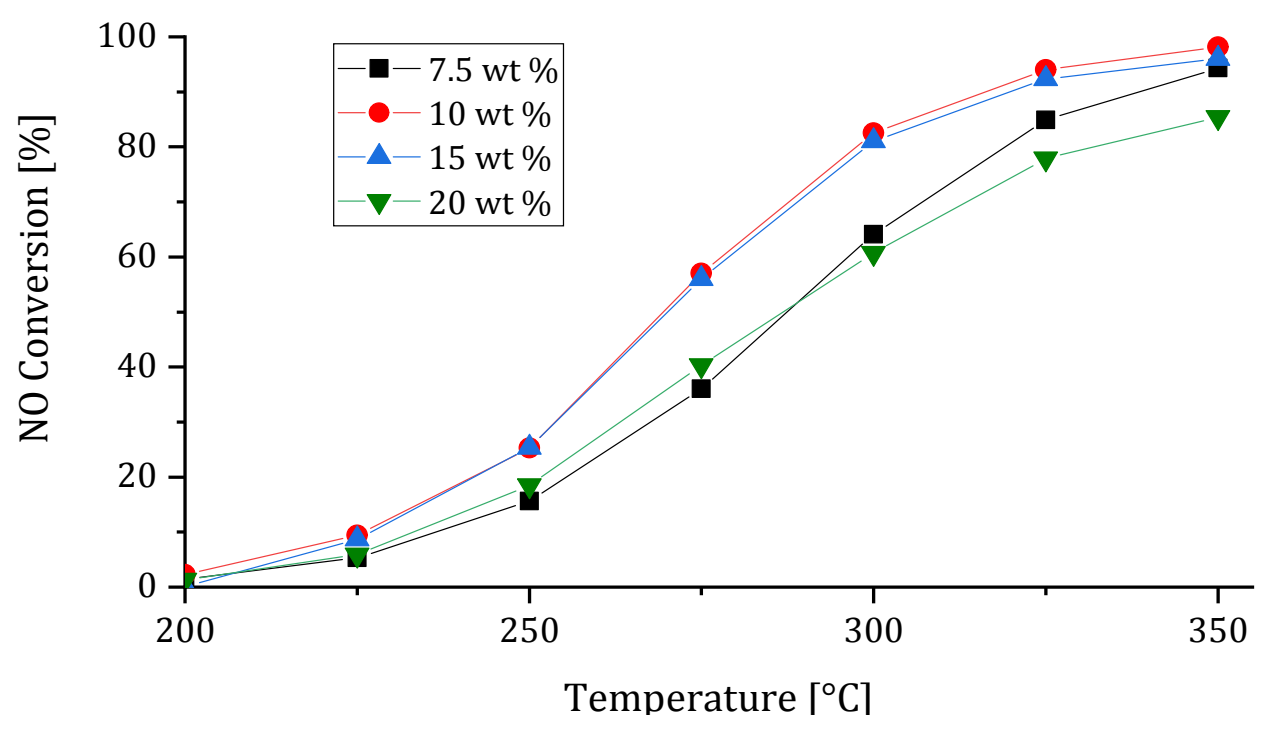

Figure 2: Comparison of $\mathrm{NO}$ conversion over temperature for 7.5, 10, 15 and 20 wt. $\% \mathrm{HPA}-3 / \mathrm{TiO}_{2}$ catalyst in $\mathrm{NH}_{3}$ SCR. Reaction conditions: $50 \mathrm{mg}$ catalyst $(180-300 \mu \mathrm{m}), 300 \mathrm{mg}$ diluting agent $\left(\mathrm{SiO}_{2}\right), 1000 \mathrm{ppm} \mathrm{NO}, 1100 \mathrm{ppm}$ $\mathrm{NH}_{3}, 4.5$ vol\% $\mathrm{O}_{2}, 2.3$ vol\% $\mathrm{H}_{2} \mathrm{O}, \mathrm{F}_{\text {tot }}=512 \mathrm{ml} \mathrm{min}^{-1}, \mathrm{~T}=200-350{ }^{\circ} \mathrm{C}$.

\section{Variation of vanadium-species on $\mathrm{TiO}_{2}$ support}

To corroborate if incorporation of vanadium into the Keggin structure of the supported HPA-3/ $/ \mathrm{TiO}_{2}$ catalyst was associated with its observed $\mathrm{NH}_{3}-\mathrm{SCR}$ activity, two reference catalyst systems were further examined based on physically mixed $\mathrm{HPA}-3$ and $\mathrm{TiO}_{2}$ as well as $\mathrm{V}_{2} \mathrm{O}_{5}$ $\mathrm{HPA}-0 / \mathrm{TiO}_{2}$ prepared by impregnation. For comparison reasons, both catalysts had the same vanadium content and V/Mo ratio as the HPA-3/TiO 2 catalyst. As shown in Figure 3, the SCR activity for the catalyst with mixed components ( $\mathrm{HPA}-3$ and $\mathrm{TiO}_{2}$ ) was very low resulting in NO conversions up to only $15 \%$ in the temperature range $200-350{ }^{\circ} \mathrm{C}$. Furthermore, the supported $\mathrm{V}_{2} \mathrm{O}_{5}-\mathrm{HPA}-0 / \mathrm{TiO}_{2}$ catalyst gave around $78 \% \mathrm{NO}$ conversion at the highest reaction temperature of $350{ }^{\circ} \mathrm{C}$. In comparison, the $\mathrm{HPA}-3 / \mathrm{TiO}_{2}$ catalyst was significantly more active possessing a $\mathrm{NO}$ conversion of around $90 \%$ at $350{ }^{\circ} \mathrm{C}$ confirming that interaction between the POM structure and support as well as vanadium incorporation into the POM structure both increased the $\mathrm{NH}_{3}$-SCR activity. 


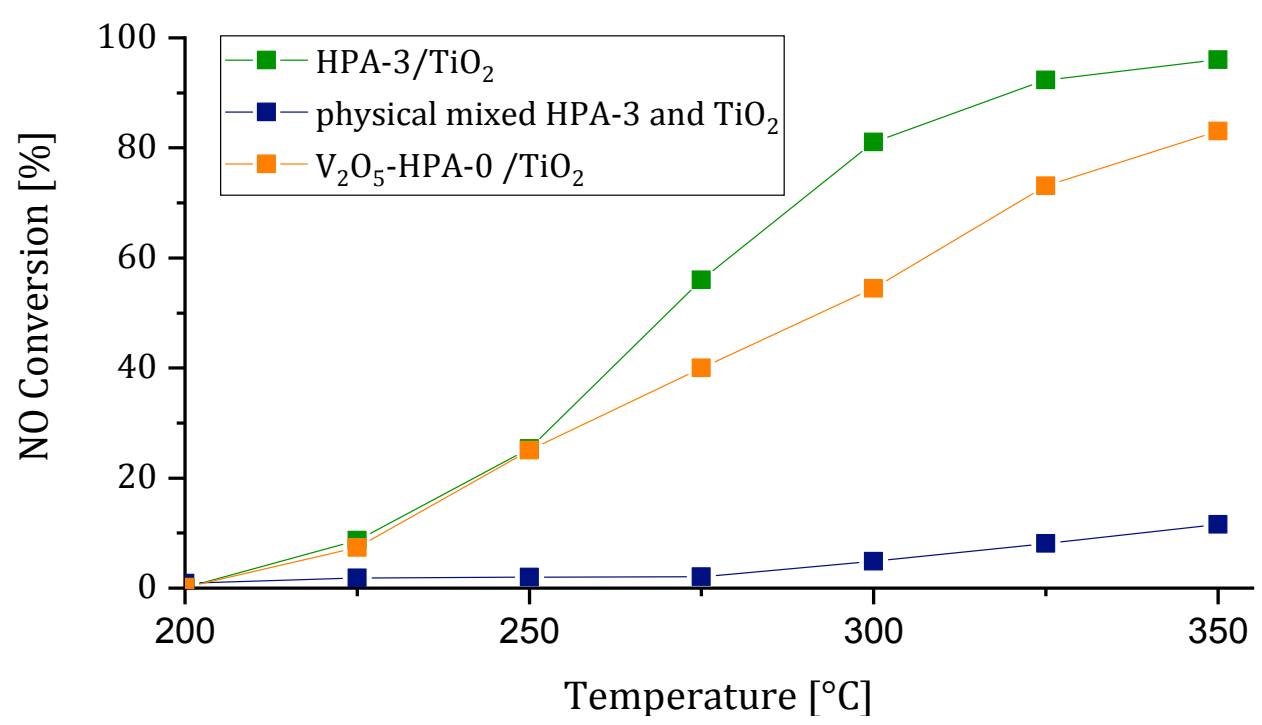

Figure 3: Comparison of NO conversion versus temperature for $10 \mathrm{wt} . \% \mathrm{HPA}-3 / \mathrm{TiO}_{2}, 10$ wt. $\% \mathrm{~V}_{2} \mathrm{O}_{5}-\mathrm{HPA}_{-}-\mathrm{O} / \mathrm{TiO}_{2}$ and physically mixed $10 \mathrm{wt} . \% \mathrm{HPA}-3$ and $\mathrm{TiO}_{2}$ catalysts. Reaction conditions: $50 \mathrm{mg}$ catalyst (180-300 $\left.\mu \mathrm{m}\right), 300 \mathrm{mg}$ diluting agent $\left(\mathrm{SiO}_{2}\right), 1000 \mathrm{ppm} \mathrm{NO}, 1100 \mathrm{ppm} \mathrm{NH}_{3}, 4.5$ vol\% $\mathrm{O}_{2}, 2.3 \mathrm{vol} \% \mathrm{H}_{2} \mathrm{O}, \mathrm{F}_{\text {tot }}=512 \mathrm{ml} \mathrm{min}^{-1}, \mathrm{~T}=200-350^{\circ} \mathrm{C}$.

\section{Activity comparison of HPA-3/support catalysts}

The catalytic activity of supported vanadium catalysts in NO-SCR are known to be effected by several factors, including redox properties, acid sides, nature of promotors and the support itself. ${ }^{42-43}$ In order to investigate the effect of the support for the supported vanadiumsubstituted POMs, catalysts based on the most active POM, HPA-3, were prepared by impregnation using different traditional supports. ICP-OES was used to determine the metal content of the different supported catalysts, resulting in Mo contents between 5.8 (supported on $\mathrm{C}$ ) and $7.5 \mathrm{wt}$ \% (supported on $\mathrm{Al}_{2} \mathrm{O}_{3}$ ) and $\mathrm{V}$ contents between 0.9 (supported on $\mathrm{C}$ ) and 2.1 wt. \% (supported on $\mathrm{ZrO}_{2}$, for more details see ESI Table S2). The results in Figure 4 clearly demonstrate that $\mathrm{HPA}-3 / \mathrm{TiO}_{2}$ had the highest SCR activity of the tested catalysts at temperatures above $200{ }^{\circ} \mathrm{C}$ yielding a NO conversion of $94 \%$ at $350{ }^{\circ} \mathrm{C}$. In comparison, HPA$3 / \mathrm{ZrO}_{2}$ gave a $\mathrm{NO}$ conversion of $38 \%$ at the highest temperature applied, whereas the NO conversion using HPA-3/C, HPA-3/SiO ${ }_{2}$ and $\mathrm{HPA}-3 / \mathrm{Al}_{2} \mathrm{O}_{3}$ was negligible under the applied reaction conditions. Therefore, $\mathrm{HPA}-3 / \mathrm{TiO}_{2}$ was selected for all further investigations. 


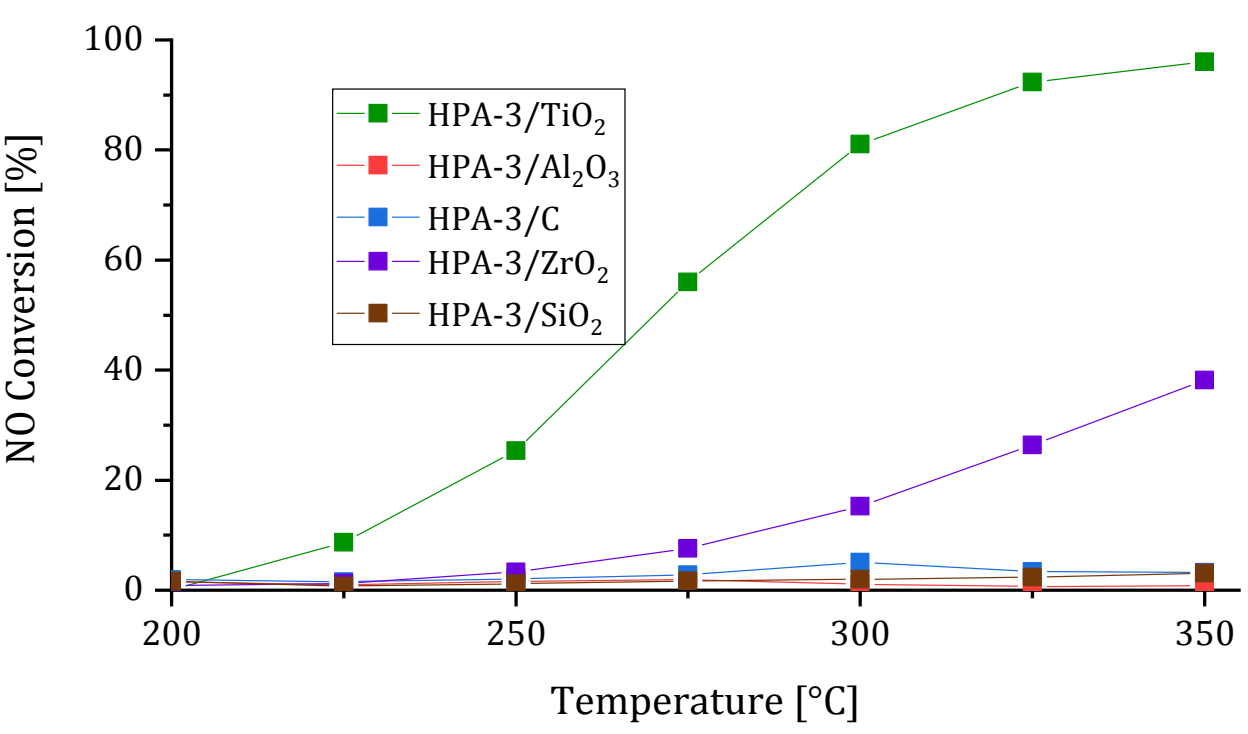

Figure 4: Comparison of $\mathrm{NO}$ conversion versus temperature for HPA-3 (15 wt.\%) based catalysts with $\mathrm{SiO}_{2}, \mathrm{Al}_{2} \mathrm{O}_{3}$, C, $\mathrm{ZrO}_{2}$ and $\mathrm{TiO}_{2}$ supports. Reaction conditions: $50 \mathrm{mg}$ catalyst $(180-300 \mu \mathrm{m}), 300 \mathrm{mg}$ diluting agent $\left(\mathrm{SiO}_{2}\right)$, $1000 \mathrm{ppm} \mathrm{NO}, 1100 \mathrm{ppm} \mathrm{NH}_{3}, 4.5$ vol\% $\mathrm{O}_{2}, 2.3$ vol\% $\mathrm{H}_{2} \mathrm{O}, \mathrm{F}_{\text {tot }}=512 \mathrm{ml} \mathrm{min}^{-1}, \mathrm{~T}=200-350^{\circ} \mathrm{C}$.

\section{Characterization of HPA-3/support catalysts}

In order to try to explain the observed difference in performance of the various supported HPA-3 catalysts, the specific surface area, pore volume and average pore diameter of all catalysts were determined by $\mathrm{N}_{2}$-physisortion. Moreover, temperature-programmed desorption (TPD) of $\mathrm{NH}_{3}$ were performed to elucidate the influence of the surface acidity on the SCRactivity. In Table 1 the physicochemical properties of the HPA-3/support catalysts are compiled.

Table 1 Textural properties and $\mathrm{NH}_{3}$-TPD results of the various $15 \mathrm{wt} . \% \mathrm{HPA}-3 /$ support catalysts.

\begin{tabular}{|l|c|c|c|c|c|}
\hline Catalyst & $\begin{array}{c}\text { BET surface } \\
\text { area }\left[\mathrm{m}^{2} / \mathrm{g}\right]\end{array}$ & $\begin{array}{c}\text { Pore vol. } \\
{\left[\mathrm{cm}^{3} / \mathrm{g}\right]}\end{array}$ & $\begin{array}{c}\text { Av. pore } \\
\text { diameter }[\AA]\end{array}$ & $\begin{array}{c}\text { Ads. } \mathrm{NH}_{3} \\
{[\mathrm{mmol} / \mathrm{g}]}\end{array}$ & $\mathrm{T}_{\max }\left[{ }^{\circ} \mathrm{C}\right]$ \\
\hline $\mathrm{HPA}-3 / \mathrm{ZrO}_{2}$ & 125.4 & 0.11 & 36.16 & 0.74 & 180.2 \\
\hline $\mathrm{HPA}-3 / \mathrm{TiO}_{2}$ & 71.5 & 0.20 & 110.34 & 0.36 & 175.6 \\
\hline $\mathrm{HPA}-3 / \mathrm{SiO}_{2}$ & 393.2 & 0.58 & 59.14 & 0.63 & 176.6 \\
\hline $\mathrm{HPA}-3 / \mathrm{Al}_{2} \mathrm{O}_{3}$ & 235.4 & 0.54 & 91.10 & 0.56 & 183.3 \\
\hline $\mathrm{HPA}-3 / \mathrm{C}$ & 598.4 & 0.84 & 56.08 & 0.69 & 186.5 \\
\hline
\end{tabular}

Interestingly, the most active catalyst $\mathrm{HPA}-3 / \mathrm{TiO}_{2}$ possessed the lowest specific surface area $\left(71.5 \mathrm{~m}^{2} / \mathrm{g}\right)$ and the largest average pore diameter $(110 \AA)$, while the second most active catalyst, $\mathrm{HPA}-3 / \mathrm{ZrO}_{2}$ had the second lowest BET area of around $125 \mathrm{~m}^{2} / \mathrm{g}$ and the smallest pore diameter ( $36 \AA$ ). Therefore, we conclude that no direct relationship between the textural properties and the SCR activity can be given. 
The $\mathrm{NH}_{3}$-SCR reaction requires $\mathrm{NH}_{3}$ to adsorb on the catalyst surface, and the numberp of ole Online surface acid sides and their strength influence the adsorption capacity and desorption patterns as a function of temperature. ${ }^{44-45}$ It is well described in the literature, that ammonia adsorption takes place on both the Brønsted and the Lewis sites on the catalyst surface. Nevertheless, the adsorption on Brønsted sites is energetically more favourable. ${ }^{45}$ Thus, the Brønsted and the Lewis sites of the POM as well as the acidic sites of the support are crucial for the ammonia adsorption. The physicochemical properties of the pure supports are compiled in the ESI, Table S3). Thus, the $\mathrm{ZrO}_{2}$ and the $\mathrm{Al}_{2} \mathrm{O}_{3}$ showed the highest $\mathrm{NH}_{3}$ adsorption $\left(0.51 \mathrm{mmol} / \mathrm{g} \mathrm{ZrO}_{2}\right.$ and $0.48 \mathrm{mmol} / \mathrm{g} \mathrm{Al}_{2} \mathrm{O}_{3}$ ) of the tested support materials. Besides the adsorption on the Brønsted acidic sites of the supported heteropolyacid, $\mathrm{NH}_{3}$ can therefore also adsorb on the Lewis acidic sites that are for example provided by the $\mathrm{Al}_{2} \mathrm{O}_{3}$ support.

To examine if the acidity of the supported HPA played an important role regarding the SCR catalyst activity, the acidity of the prepared HPA-3/support catalysts was measured using $\mathrm{NH}_{3}-$ TPD and the results are included in Table 1. Here, $\mathrm{HPA}-3 / \mathrm{ZrO}_{2}$ showed the highest $(0.74 \mathrm{mmol} / \mathrm{g})$ and $\mathrm{HPA}-3 / \mathrm{TiO}_{2}$ the lowest $(0.36 \mathrm{mmol} / \mathrm{g})$ number of acid sites, and the latter gave the lowest desorption temperature (i.e. weakest acid sites). Thus, no clear trend between the $\mathrm{NH}_{3}$-TPD measurements of the supported POM-catalysts, the acidity of the pure supports and the SCR performance was observed suggesting that active POM surface species were linked to the observed catalytic activity.

To investigate the promoting effect of $\mathrm{TiO}_{2}$ on the SCR performance FTIR ATR analysis was further carried out on the various supported HPA-3 catalysts as well as the bulk HPA-3 as a reference. Additionally, reference measurements of the blank supports were also performed (for details see ESI, Figure S10). Figure 5 shows the obtained FTIR spectra for the HPA-3 catalysts based on the different supports $\left(\mathrm{Al}_{2} \mathrm{O}_{3}, \mathrm{C}, \mathrm{SiO}_{2}, \mathrm{ZrO}_{2}\right.$, and $\left.\mathrm{TiO}_{2}\right)$ and bulk HPA-3. The characteristic stretching vibrations of the Keggin-oxoanion were in all samples observed at $1045 \mathrm{~cm}^{-1}\left(\mathrm{~V}_{\mathrm{as}} \mathrm{P}-\mathrm{O}_{\mathrm{a}}\right), 948 \mathrm{~cm}^{-1}\left(\mathrm{~V}_{\mathrm{as}} \mathrm{Mo}-\mathrm{O}_{\mathrm{d}}\right), 869 \mathrm{~cm}^{-1}\left(\mathrm{v}_{\mathrm{as}} \mathrm{Mo}-\mathrm{O}_{\mathrm{b}}-\mathrm{Mo}\right)$ and $739 \mathrm{~cm}^{-1}\left(\mathrm{~V}_{\mathrm{as}} \mathrm{M}-\mathrm{O}_{\mathrm{b}}-\right.$ $\mathrm{Mo})$, which were at slightly lower wavenumbers compared to the non-substituted HPA-0 as also previously reported elsewhere ${ }^{44}\left(\mathrm{O}_{\mathrm{a}}\right.$ refers to the oxygen atom common to $\mathrm{PO}_{4}$ tetrahedron and one trimetallic group $\mathrm{Mo}_{3} \mathrm{O}_{13} ; \mathrm{O}_{b}$ connects two trimetallic groups; $\mathrm{O}_{c}$ binds two octahedral $\mathrm{MoO}_{6}$ inside a trimetallic group, and $\mathrm{O}_{\mathrm{d}}$ is the terminal oxygen atom). The presence of the characteristic vibrations indicated that the POM structure prevailed in the supported samples, however the intensity of the bands strongly depended on the nature of the support and were most pronounced with $\mathrm{SiO}_{2}$ and $\mathrm{C}$. Hence, also here no clear trend between the FTIR ATR analysis and the SCR performance was evident. 


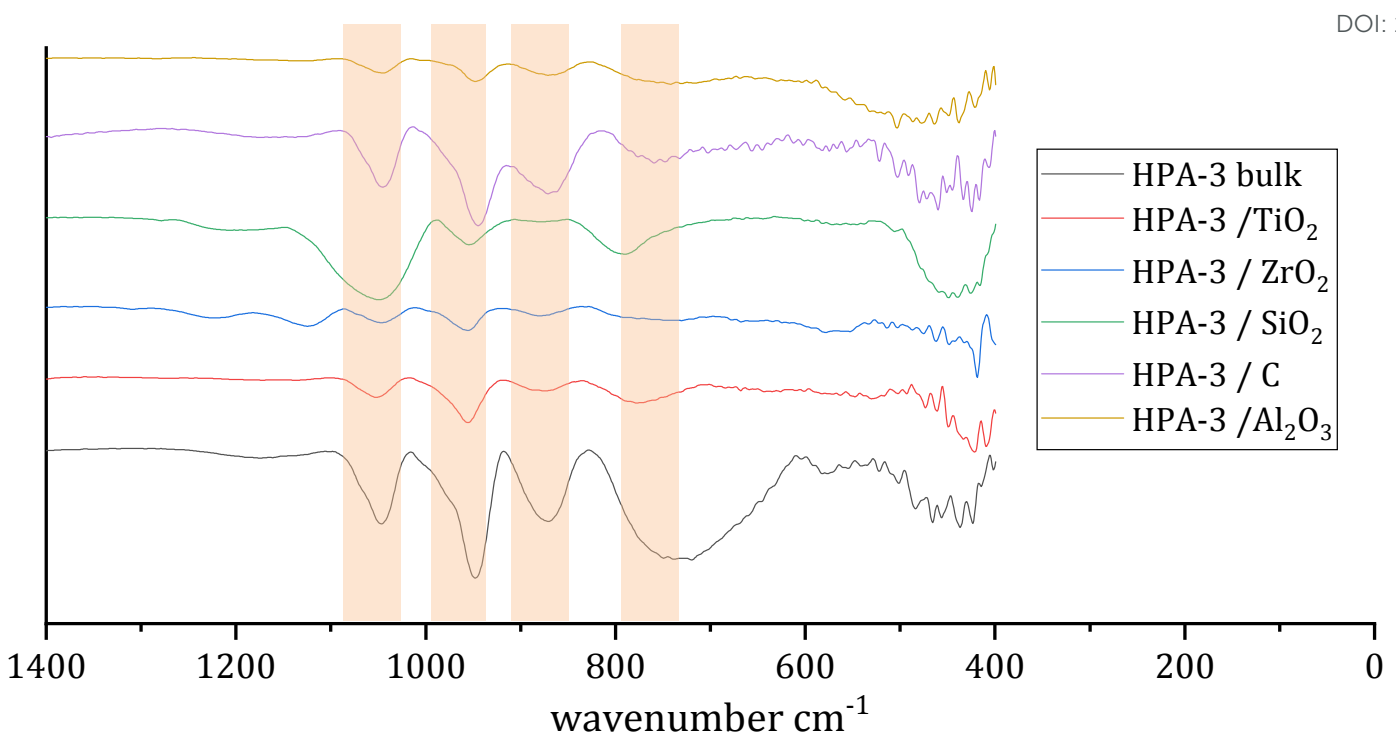

Figure 5: FTIR spectra of HPA-3/support catalysts with the different supports $\mathrm{TiO}_{2}, \mathrm{ZrO}_{2}, \mathrm{SiO}_{2}, \mathrm{C}$ and $\mathrm{Al}_{2} \mathrm{O}_{3}$.

\section{Characterization of HPA-3/TiO 2 catalyst before/after SCR reaction}

Post-reaction characterization of the superior $\mathrm{HPA}-3 / \mathrm{TiO}_{2}$ catalyst was performed to investigate structural transformations and possible instabilities of the POM structure on the support surface during reaction, which potentially limit long-term application. Figure 6 shows representative TEM images of both the fresh $\mathrm{HPA}-3 / \mathrm{TiO}_{2}$ catalyst (top) and the catalyst after being used for the SCR reaction (bottom). In both catalysts, the POM particles (small white dots) were well dispersed and uniformly distributed on the support surface without cluster formation, suggesting a good access of substrate to the active centres and good thermal stability. 

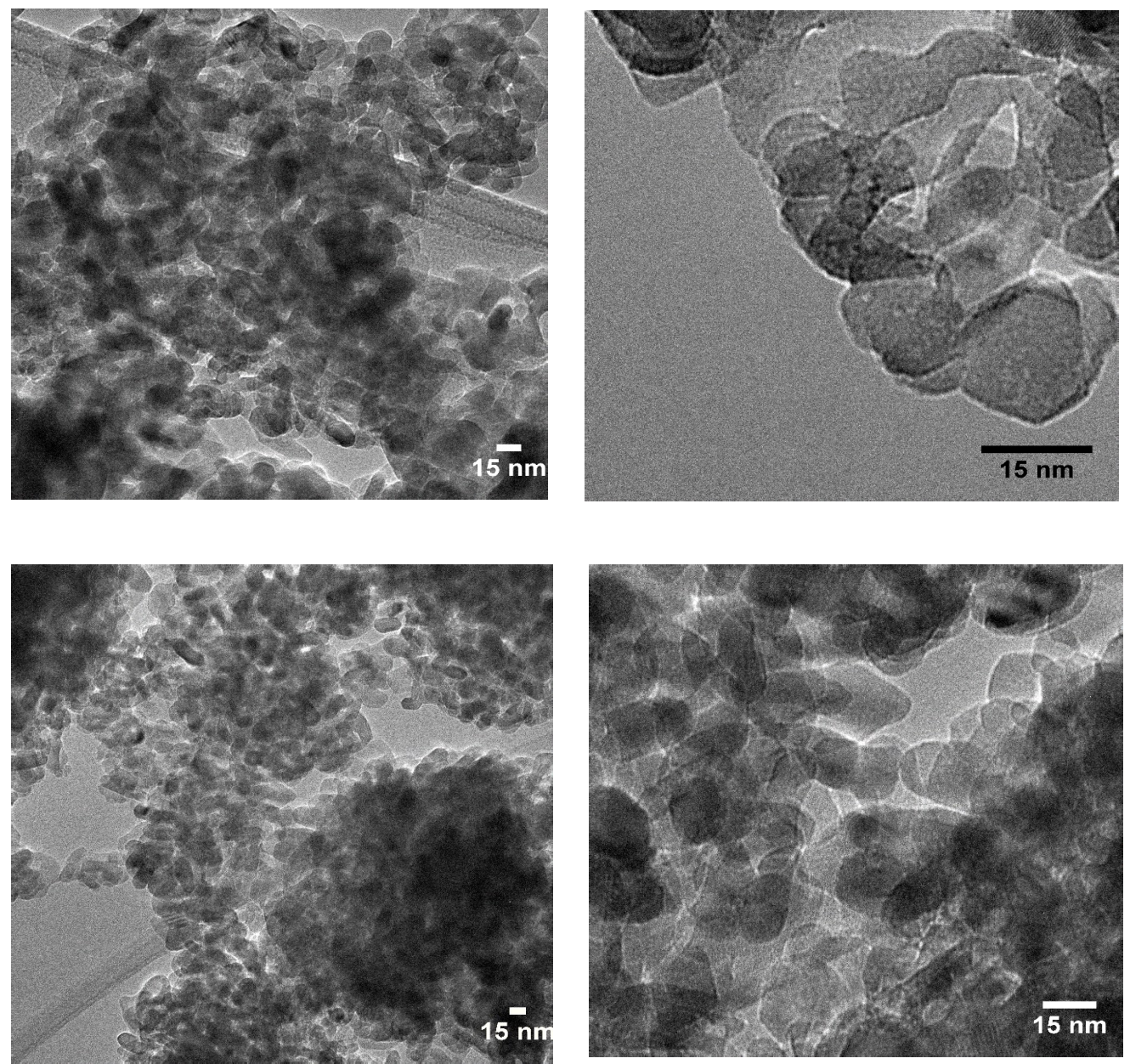

Figure 6: TEM images of fresh $\mathrm{HPA}-3 / \mathrm{TiO}_{2}$ (top) and $\mathrm{HPA}-3 / \mathrm{TiO}_{2}$ after SCR use (bottom).

XPS spectra of the as-prepared $\mathrm{HPA}-3 / \mathrm{TiO}_{2}$ catalyst (top) and the analogous catalyst after SCR use (bottom) are shown in Figure 7. For both samples, the molybdenum spectra (left) revealed binding energies around 232.5 and $236.3 \mathrm{eV}$ corresponding to $\mathrm{Mo}^{6+}$ species, while no lower binding energies corresponding to reduced Mo species were observed. ${ }^{46}$ The vanadium spectra (right) of the samples showed also similar binding energies around 516.2 and $517.0 \mathrm{eV}$ corresponding to $\mathrm{V}^{4+}$ and $\mathrm{V}^{5+}$, respectively. ${ }^{47} \mathrm{Via}$ integration of the corresponding peak area the ratios of $\mathrm{V}^{4+}$ to $\mathrm{V}^{5+}$ in the fresh and used $\mathrm{HPA}-3 / \mathrm{TiO}_{2}$ catalyst was determined to be 53 to $47 \%$ and 58 to $42 \%$, respectively, thus revealing no significant changes in the oxidation states of molybdenum and vanadium in the catalysts. 

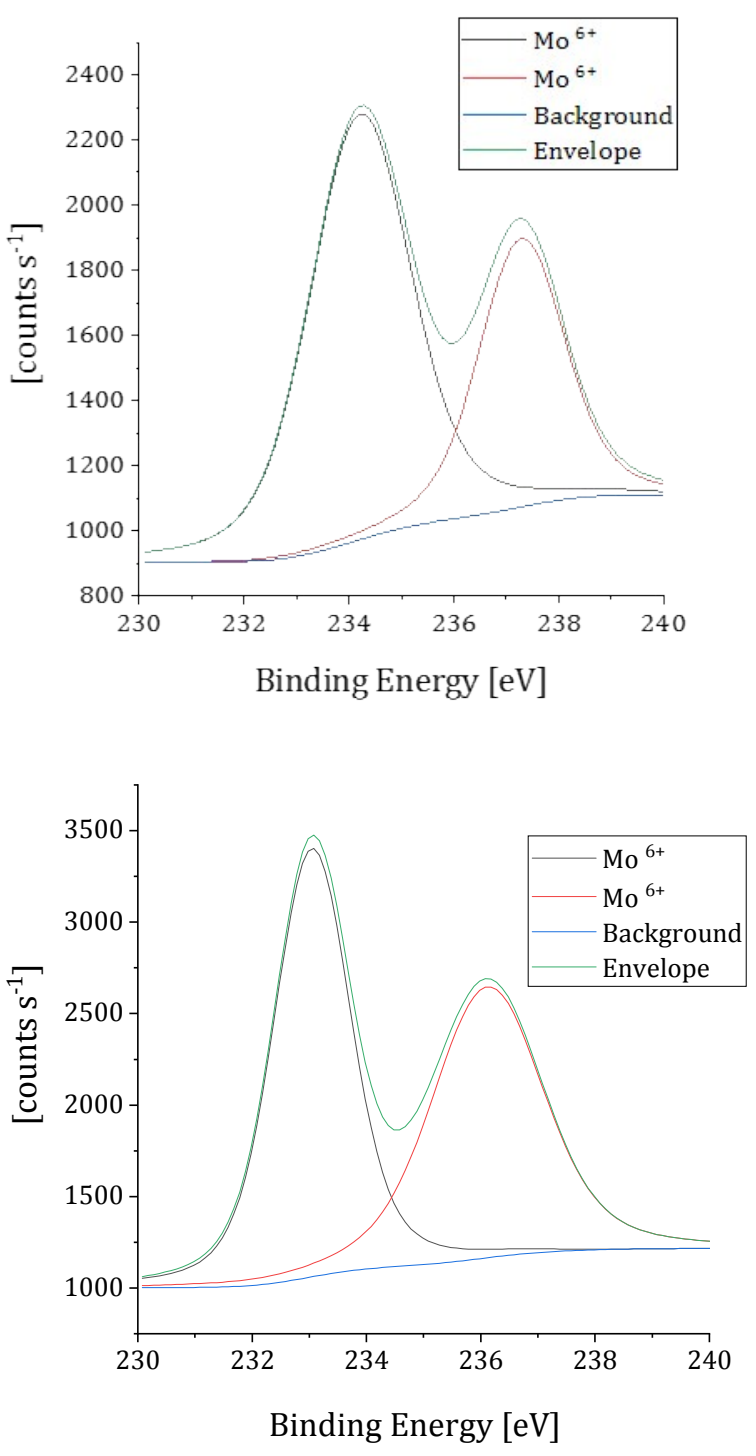

View Article Online DOI: 10.1039/DORE00033G
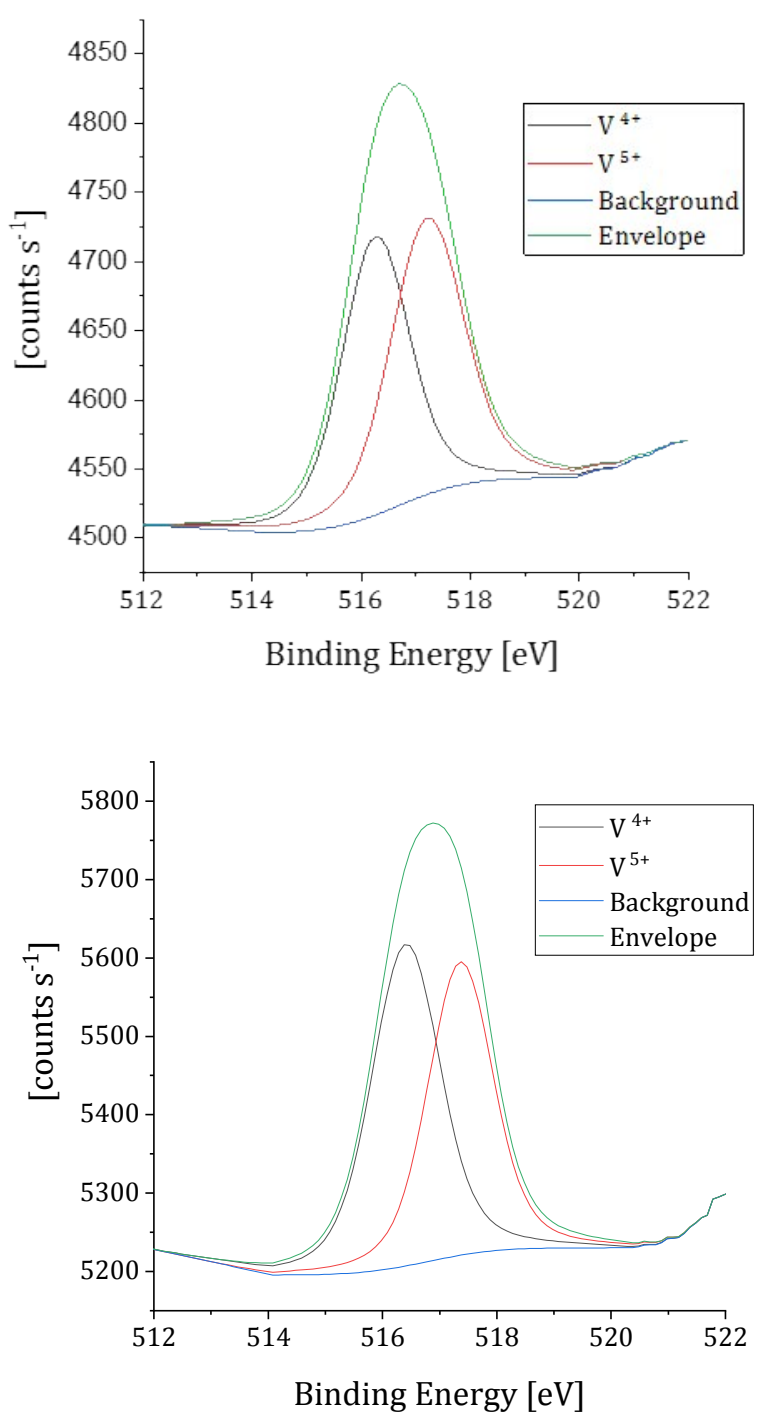

Figure 7: XPS spectra of fresh $\mathrm{HPA}-3 / \mathrm{TiO}_{2}$ (top) and $\mathrm{HPA}-3 / \mathrm{TiO}_{2}$ after SCR use (bottom) with molybdenum (left) and vanadium (right) binding energies.

The presence of the POM structure in the HPA-3/TiO 2 catalyst used for the SCR reaction was recognized by FTIR analysis as shown by the spectra in Figure 8 . Here, the characteristic stretching vibrations of the Keggin-oxoanion were identified at $1065 \mathrm{~cm}^{-1}\left(\mathrm{~V}_{\mathrm{as}} \mathrm{P}-\mathrm{O}_{\mathrm{a}}\right), 959 \mathrm{~cm}^{-1}$ $\left(\mathrm{V}_{\mathrm{as}} \mathrm{Mo}_{\mathrm{O}} \mathrm{O}_{\mathrm{d}}\right), 865 \mathrm{~cm}^{-1}\left(\mathrm{v}_{\mathrm{as}} \mathrm{Mo}-\mathrm{O}_{\mathrm{b}}-\mathrm{Mo}\right)$ and $771 \mathrm{~cm}^{-1}\left(\mathrm{v}_{\mathrm{as}} \mathrm{M}-\mathrm{O}_{\mathrm{b}}-\mathrm{Mo}\right)$, respectively, demonstrating that no critical structural transformations or instabilities of the POM structure occurred during catalysis. Notably, the intensity of the signals in the spent catalyst were weaker than the signals for the HPA-3/TiO 2 catalyst, because the sample was diluted with $\mathrm{SiO}_{2}$ (diluting agent in $\mathrm{NH}_{3}$ SCR). 


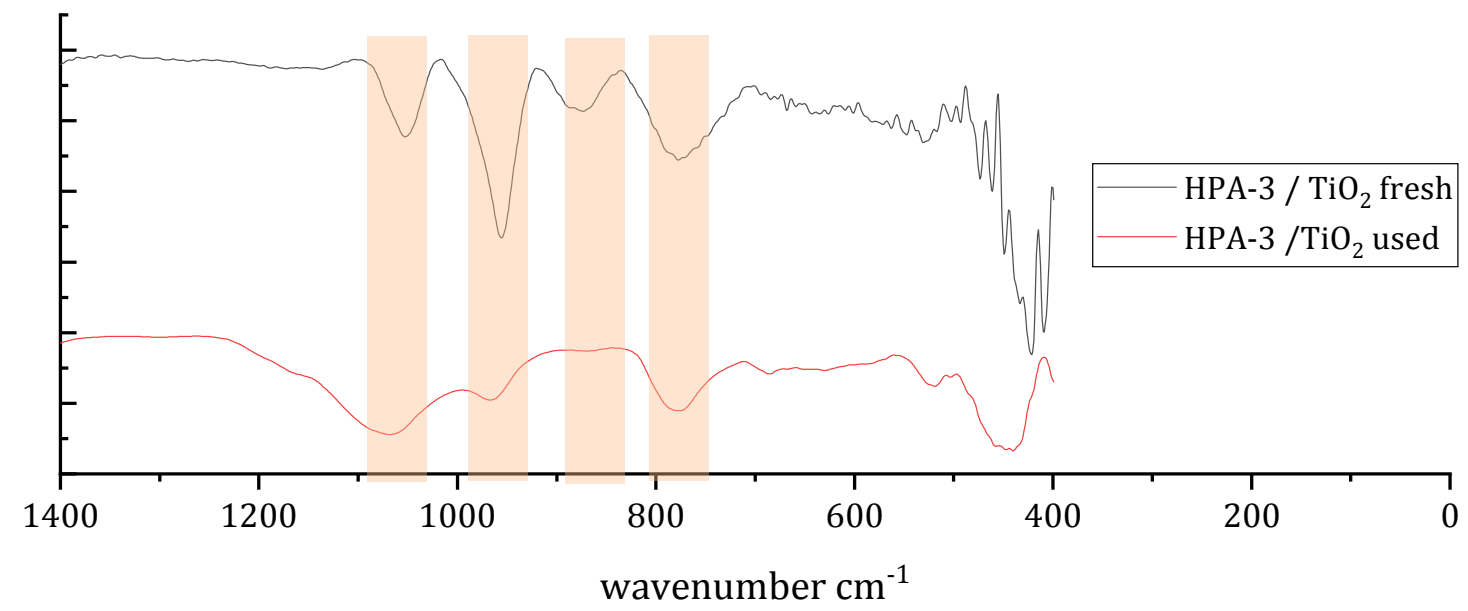

Figure 8: FTIR spectra of fresh $\mathrm{HPA}-3 / \mathrm{TiO}_{2}$ (top) and $\mathrm{HPA}-3 / \mathrm{TiO}_{2}$ after SCR use (bottom) with wavenumbers ranges of the stretching vibrations of the Keggin-oxoanion highlighted.

\section{In-situ EPR spectroscopy of the-supported HPA catalysts}

In order to explain the catalytic behavior and to get a deeper understanding of the POM-support interactions, in-situ EPR studies were performed on HPA-3/TiO $, \mathrm{HPA}-3 / \mathrm{Al}_{2} \mathrm{O}_{3}, \mathrm{HPA}-0$ and $\mathrm{V}_{2} \mathrm{O}_{5} / \mathrm{TiO}_{2}$ under different gas exposures relevant for SCR, i.e. $\mathrm{NH}_{3}, \mathrm{NH}_{3} / \mathrm{NO}, \mathrm{O}_{2} / \mathrm{NO}$ and $\mathrm{NH}_{3} / \mathrm{NO} / \mathrm{O}_{2}$, at temperatures of $25-290{ }^{\circ} \mathrm{C}$. As described below all observed spectra can be assigned to $\mathrm{V}^{4+}$ species. No signal for reduced $\mathrm{Mo}^{5+}$ was observed.

The EPR spectra of the fresh catalyst samples before gas exposure are shown in Figure 9 (top). The $\mathrm{TiO}_{2}$ supported samples HPA-3/TiO 2 and $\mathrm{V}_{2} \mathrm{O}_{5}-\mathrm{HPA}-0 / \mathrm{TiO}{ }_{2}$ provided similar spectra, whereas $\mathrm{HPA}-3 / \mathrm{Al}_{2} \mathrm{O}_{3}$ showed an EPR signal with low intensity. The spectra were typical for the solid state of $\mathrm{V}^{4+}$ as vanadyl $\left([\mathrm{VO}]^{2+}\right)$ species in a tetragonal coordination environment. ${ }^{48-}$ ${ }^{49} \mathrm{~A}$ small signal at $g=4.3$ was observed in $\mathrm{HPA}-3 / \mathrm{Al}_{2} \mathrm{O}_{3}$ originating from impurities in the alumina support, likely a small amount of iron oxides (see Figure S3). A broad and temperature dependent signal from the same impurity was centered at $g=2.0$, making quantification of the signal difficult, especially when the intensity of the vanadium signal was low.

Upon exposing the supported samples to a flow of 4.5 vol\% $\mathrm{O}_{2}$ and 2.3 vol. $\% \mathrm{H}_{2} \mathrm{O}$ in balance $\mathrm{He}$ at room temperature the spectra changed as shown in Figure 9 (left). The EPR spectra can be modeled with the spin Hamiltonian

$$
H=g_{x} S_{x} B_{x}+g_{y} S_{y} B_{y}+g_{z} S_{z} B_{z}+A_{x} S_{x} I_{x}+A_{y} S_{y} I_{y}+A_{z} S_{z} I_{z}
$$

where $g_{i}$ and $A_{i}$ are the electronic g-values and hyperfine coupling constants along the molecular aces $(i=x, y, z)$, respectively (see ESI for details on the modeling). The spectra of water exposed samples were isotropic (i.e. the observed $g$ - and $A$ tensors were independent of molecular axes and can each be represented by a single value) with $g_{\text {iso }}=1.96$ and $A_{\text {iso }}=$ $318 \mathrm{MHz}$. This species have previously been assigned to $\left[\mathrm{VO}\left(\mathrm{H}_{2} \mathrm{O}\right)_{5}\right]^{2+} \cdot{ }^{31}$ Isotropic spectra indicated that the EPR active [VO] ${ }^{2+}$ either changes the anisotropy axis or rotates fast on the EPR time scale. This species became even more dominant when the $\mathrm{TiO}_{2}$ supported catalysts were exposed to a moist gas flow, whereas the $\mathrm{Al}_{2} \mathrm{O}_{3}$ supported sample was not responsive. 
When heating the samples in the same gas flow, the relative humidity decreased below $100 \%$ o/cle Online and the spectrum rapidly changed to reveal EPR active $[\mathrm{VO}]^{2+}$ species with a more complicated and anisotropic (axial) EPR spectra $\left(g_{x}=g_{y} \neq g_{z}\right)$, see Figure 9 (right). When subsequently cooling the samples to room temperature, the isotropic signal did not reoccur right away indicating that the change was quite slow or irreversible. Exposing a fresh catalyst to a dry flow $\left(4.5 \mathrm{vol} \% \mathrm{O}_{2}\right.$ in $\left.\mathrm{He}\right)$ at room temperature resulted in a similar axial spectrum.

\begin{tabular}{|c|c|c|c|c|c|c|c|}
\hline \multicolumn{8}{|c|}{ g-value } \\
\hline 4.8 & 3.7 & 3.0 & 25 & 2.3 & 2.0 & 1.8 & 1.6 \\
\hline
\end{tabular}

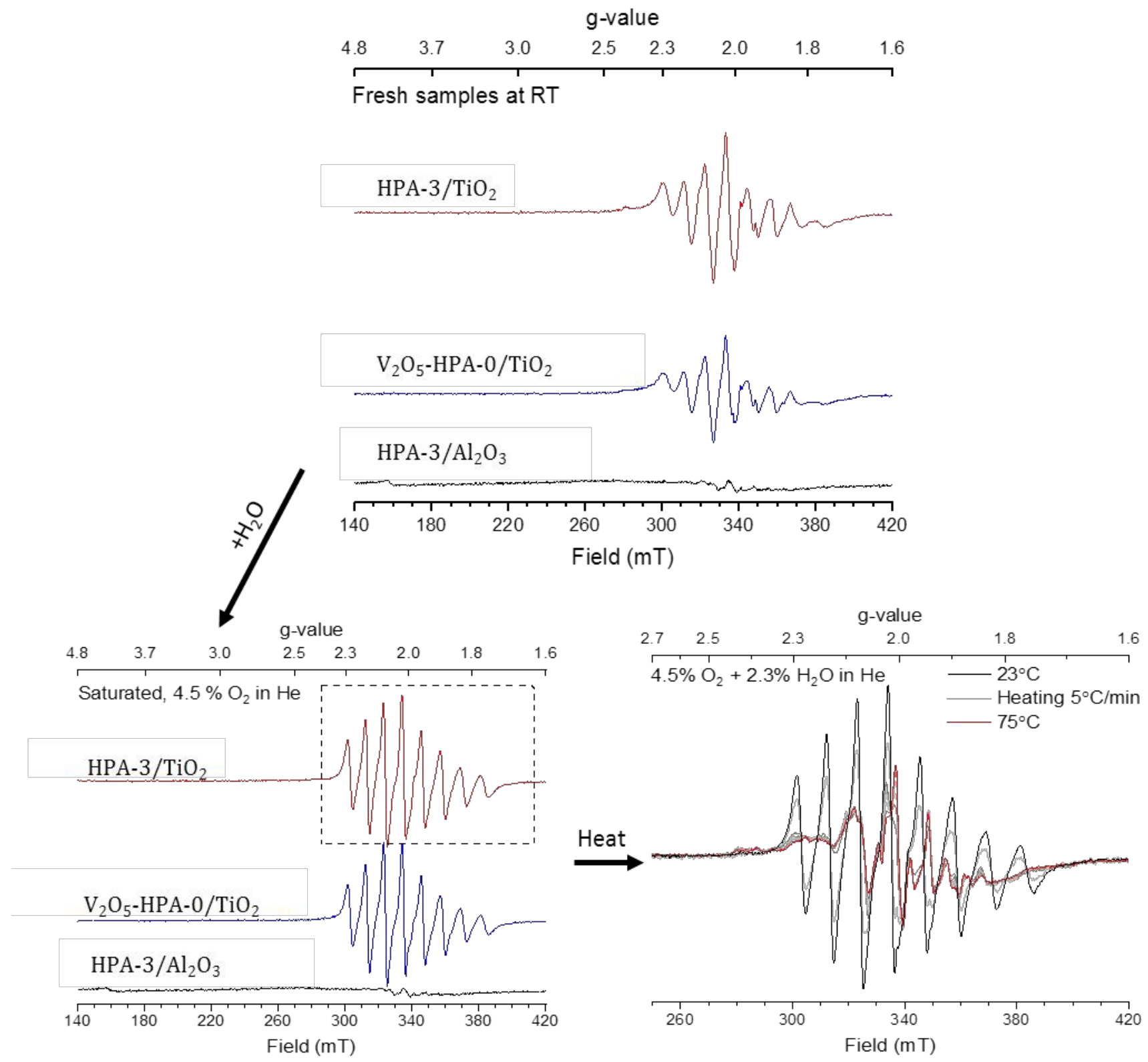

Figure 9: $\mathrm{EPR}$ spectra of fresh $\mathrm{HPA}-3 / \mathrm{TiO}_{2}, \mathrm{~V}_{2} \mathrm{O}_{5}-\mathrm{HPA}-0 / \mathrm{TiO}_{2}$ and $\mathrm{HPA}-3 / \mathrm{Al}_{2} \mathrm{O}_{3}$ catalysts at room temperature measured as the first spectrum of the in-situ measurement without gas exposure (top) and after exposure to $2.3 \mathrm{vol} \% \mathrm{H}_{2} \mathrm{O}$ (saturated) and $4.5 \mathrm{vol} \% \mathrm{O}_{2}$ in $\mathrm{He}$ at room temperature (left). Change in EPR spectra of $\mathrm{HPA}-3 / \mathrm{TiO}_{2}$ as the gas flow was kept constant at $2.3 \mathrm{vol} \% \mathrm{H}_{2} \mathrm{O}+4.5 \% \mathrm{O}_{2}$ in $\mathrm{He}$ and the temperature was raised by $5{ }^{\circ} \mathrm{C} / \mathrm{min}$.

The catalysts were exposed to cycles of reducing $\left(\mathrm{NH}_{3} / \mathrm{NO}\right.$ gas $)$ and oxidizing $\left(\mathrm{NO} / \mathrm{O}_{2}\right.$ gas $)$ conditions at $250{ }^{\circ} \mathrm{C}$ in order to quantify the amount of $[\mathrm{VO}]^{2+}$ and to follow the reduction of vanadium under SCR conditions. The development in the EPR intensity and the individual spectra during such gas exposures are shown in Figure 10 left and right, respectively. The 
results showed that exposure to $\mathrm{NO} / \mathrm{O}_{2}$ caused a rapid decrease of the EPR signal intensitycle Online for all the samples with paramagnetic $[\mathrm{VO}]^{2+}$ likely being oxidized into (EPR inactive) diamagnetic $\mathrm{V}^{5+}$ (a small amount of vanadium remained as [VO] ${ }^{2+}$ ). Analogously, exposure to $\mathrm{NO} / \mathrm{NH}_{3}$ caused an increase in signal intensity as $\mathrm{V}^{5+}$ was reduced to $[\mathrm{VO}]^{2+}$. The reduction proceeded slower than the oxidation for all samples. Moreover, the $\mathrm{TiO}_{2}$ supported samples responded faster and more efficiently to the $\mathrm{NH}_{3}$ and $\mathrm{NO}$ gases than the $\mathrm{Al}_{2} \mathrm{O}_{3}$ supported sample. The EPR signal intensity in Figure 10 was calculated by double integration of individual background-corrected spectra for all samples. The analysis of the EPR signal of the HPA$3 / \mathrm{Al}_{2} \mathrm{O}_{3}$ sample was complicated by a contribution from a non-vanadium paramagnetic impurity. The quantification for this sample are less reliable than for the other samples. A more careful analysis of the spectrum suggests that the amount of EPR active vanadium may be as low as $0.05 \mathrm{wt} . \%$ for this sample. About $11 \%$ of the $\mathrm{V}$ in the fresh $\mathrm{HPA}-3 / \mathrm{TiO}_{2}$ was observed as EPR active $\mathrm{V}^{4+}$, see ESI, Figure S2-S7 and a maximum amount of $25 \%$ could be detected under reaction conditions.

The EPR spectra of the three samples exposed to different gas mixtures revealed that HPA$3 / \mathrm{Al}_{2} \mathrm{O}_{3}$ only contained $\mathrm{V}^{4+}$ species of type $\mathrm{B}$, see Figure 10 . The amount changes with exposure to the different gases, but no other EPR active species appeared. In contrast, the two $\mathrm{TiO}_{2}$ supported catalysts showed overlapping EPR signals from at least three different species: Two distinct species with well-resolved hyperfine coupling patterns (type A and B) and one species with unresolved features, which can be modeled as being isotropic (type $C$ ). The distribution of sites changes when the sample is exposed to the different gas mixtures. The results of the analysis using simulations of the spectra in Figure 10 (right) are given in Table 2. Simulated spectra can be seen in Figure S4. The maximum amount of EPR active vanadium is found under reducing conditions. It is given in Table 2 , rightmost column as the percentage of the total amount of vanadium present. The values obtained when combining $A$, $\mathrm{B}$ and $\mathrm{C}$ are comparable for HPA-3 on $\mathrm{TiO}_{2}$ and for $\mathrm{V}_{2} \mathrm{O}_{5} / \mathrm{HPA}-0$ on $\mathrm{TiO}_{2}$ at $19 \%$ and $24 \%$, respectively. 

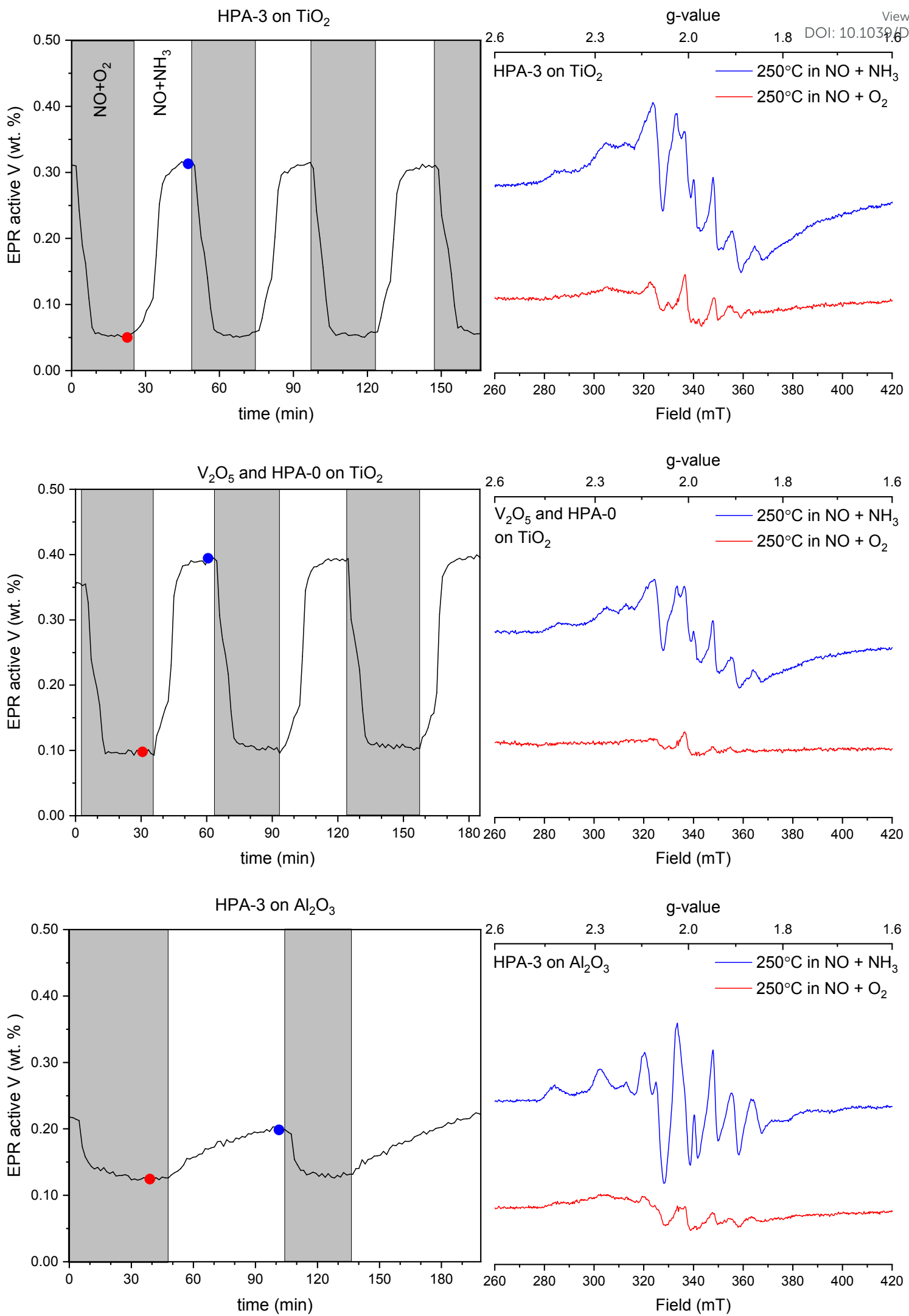

Figure 10: EPR active vanadium in wt. $\%$ of sample during in-situ experiments with $\mathrm{HPA}-3 / \mathrm{TiO}_{2}, \mathrm{~V}_{2} \mathrm{O}_{5}-\mathrm{HPA}_{-0}-\mathrm{TiO}_{2}$ and $\mathrm{HPA}-3 / \mathrm{Al}_{2} \mathrm{O}_{3}$ catalysts at $250{ }^{\circ} \mathrm{C}$. White columns represent exposure to $550 \mathrm{ppm} \mathrm{NH} / 500 \mathrm{ppm} \mathrm{NO}$ in 2.3 vol\% $\mathrm{H}_{2} \mathrm{O}$ and balance $\mathrm{He}$. Grey columns represent exposure to $500 \mathrm{ppm} \mathrm{NO} / 4.5$ vol\% $\mathrm{O}_{2}$ in 2.3 vol\% $\mathrm{H}_{2} \mathrm{O}$ and balance $\mathrm{He}$. The colored dots show which spectra were selected for plotting to the right with same color. 
Table 2: Simulated spin Hamiltonian values as well as fitted linewidth (given as full width at half maximum) fonthecle Online $\mathrm{HPA}-3 / \mathrm{TiO}_{2}, \mathrm{~V}_{2} \mathrm{O}_{5}-\mathrm{HPA}-0 / \mathrm{TiO}_{2}$ and $\mathrm{HPA}-3 / \mathrm{Al}_{2} \mathrm{O}_{3}$ catalysts under different conditions (see Figures S5-S 1 ): $1039 / \mathrm{D} 0 \mathrm{RE} 00033 \mathrm{G}$

\begin{tabular}{|c|c|c|c|c|c|c|c|c|c|c|c|}
\hline Catalyst & Gas $^{a}$ & Type & $g_{x} g_{y}$ & $g_{z}$ & $g_{\text {iso }}$ & $\begin{array}{l}A_{x,} A_{y} \\
{[\mathrm{MHz}]}\end{array}$ & $\begin{array}{c}A_{\mathrm{z}} \\
{[\mathrm{MHz}]}\end{array}$ & $\begin{array}{c}A_{\text {iso }} \\
{[\mathrm{MHz}]}\end{array}$ & $\begin{array}{c}\text { FWHM } \\
{[\mathrm{mT}]}\end{array}$ & $\begin{array}{l}\% \text { of } \\
\text { signal }\end{array}$ & $\begin{array}{c}\mathrm{V}_{\text {EPR }} / V_{\text {ICP }}{ }^{b} \\
{[\%]}\end{array}$ \\
\hline \multirow[t]{5}{*}{ HPA-3/TiO 2} & Ox. & A & 1.97 & 1.93 & 1.96 & 155 & 490 & 267 & 3.1 & 19 & 1 \\
\hline & & C & - & - & 1.96 & - & - & - & 38 & 81 & 3 \\
\hline & Red. & $A$ & 1.97 & 1.93 & 1.96 & 155 & 460 & 257 & 3.2 & 4 & 1 \\
\hline & & B & 1.98 & 1.92 & 1.96 & 195 & 510 & 300 & 3.8 & 11 & 2 \\
\hline & & $\mathrm{C}$ & - & - & 1.96 & - & - & - & 38 & 85 & 16 \\
\hline \multirow{5}{*}{$\begin{array}{l}\mathrm{V}_{2} \mathrm{O}_{5}-\mathrm{HPA}-\mathrm{O} / \\
\mathrm{TiO}_{2}\end{array}$} & Ox. & $A$ & 1.97 & 1.93 & 1.96 & 155 & 490 & 267 & 3.2 & 30 & 2 \\
\hline & & C & - & - & 1.96 & - & - & - & 38 & 70 & 4 \\
\hline & Red. & $A$ & 1.97 & 1.93 & 1.96 & 155 & 460 & 257 & 3.2 & 7 & 2 \\
\hline & & $B$ & 1.98 & 1.92 & 1.96 & 195 & 510 & 300 & 2.8 & 8 & 2 \\
\hline & & $\mathrm{C}$ & - & - & 1.96 & - & - & - & 38 & 85 & 20 \\
\hline \multirow[t]{2}{*}{$\mathrm{HPA}-3 / \mathrm{Al}_{2} \mathrm{O}_{3}$} & Ox. & B & 1.98 & 1.93 & 1.96 & 190 & 510 & 297 & 3.5 & 100 & $<12$ \\
\hline & Red. & $B$ & 1.98 & 1.93 & 1.96 & 185 & 505 & 292 & 3.5 & 100 & $<17$ \\
\hline
\end{tabular}

a Ox. represents oxidizing condition with a gas flow of $200 \mathrm{~mL} / \mathrm{min}$ containing $4.5 \mathrm{vol} \% \mathrm{O}_{2}, 500 \mathrm{ppm} \mathrm{NO}$ and 2.3 vol\% $\mathrm{H}_{2} \mathrm{O}$ in balance $\mathrm{He}$ at $250{ }^{\circ} \mathrm{C}$. Red. is reducing conditions in a gas flow of $200 \mathrm{~mL} / \mathrm{min}$ containing $550 \mathrm{ppm}$ $\mathrm{NH}_{3}, 500 \mathrm{ppm} \mathrm{NO}$ and 2.3 vol\% $\mathrm{H}_{2} \mathrm{O}$ at $250{ }^{\circ} \mathrm{C}$. ${ }^{\mathrm{b}} \mathrm{V}_{\mathrm{EPR}} / \mathrm{V}_{\mathrm{ICP}}$ refers to the amount of vanadium that is EPR active based on the calculated intensity relative to the initial EPR spectrum and the amount of $\mathrm{V}$ as determined by ICP. The intensity of EPR spectra were Boltzmann corrected according the temperature of the relevant spectrum.

The HPA-3/ $\mathrm{TiO}_{2}$ catalyst was further examined by EPR under operando SCR conditions at temperatures from $175-290{ }^{\circ} \mathrm{C}$, and spectra from selected temperatures are shown in Figure 11. No significant change in the EPR signal was observed (except a slight line broadening), when the temperature was increased. Furthermore, the sample was kept at 290 ${ }^{\circ} \mathrm{C}$ under SCR conditions for 30 minutes without any change in the EPR signal, indicating no further change in the distribution of EPR active species under these conditions. 


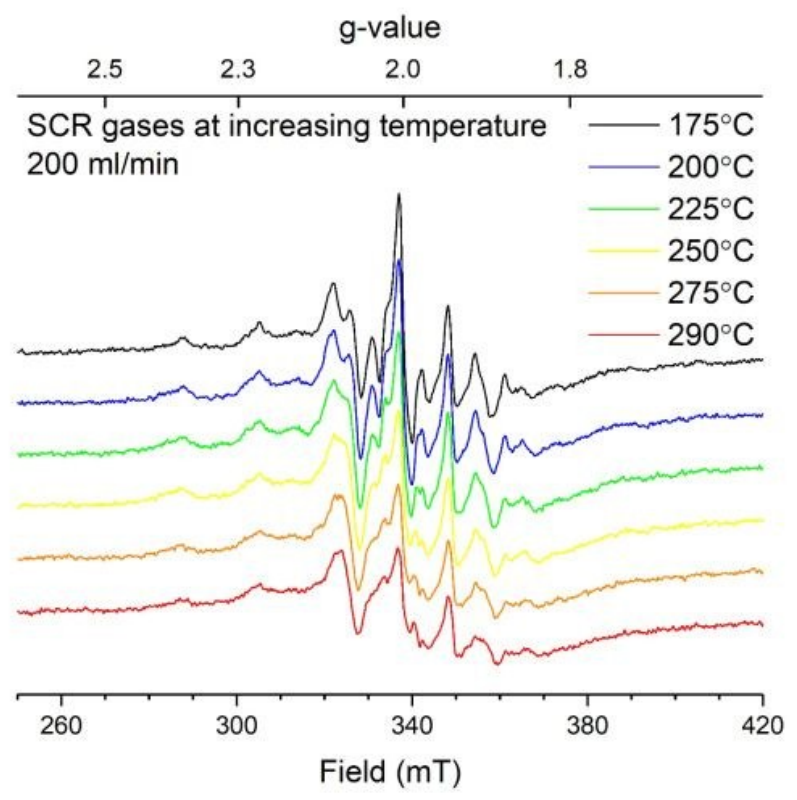

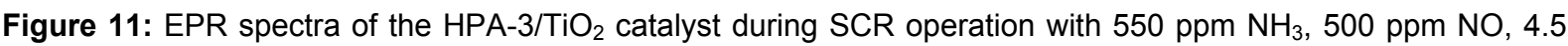
vol\% $\mathrm{O}_{2}$ and 2.3 vol\% $\mathrm{H}_{2} \mathrm{O}$ in $\mathrm{He}, \mathrm{F}_{\text {tot }}=200 \mathrm{~mL} / \mathrm{min}$ at increasing temperatures.

The g- and A-values averaged over the different axes (the isotropic values) can be plotted as $g_{i s o}$ vs. $A_{\text {iso }}$ as shown in Figure 12. This empirical plot is often used in the literature, ${ }^{49}$ since the different regions are indicative of different types of vanadium species. The alpha area corresponds to square pyramidal or axially distorted octahedral $\mathrm{V}^{4+}$ species. The beta area is characteristic of tetrahedral $\mathrm{V}^{4+}$ species and the gamma area corresponds to $\mathrm{V}^{4+}$ with biaxially distorted octahedral symmetry. All the vanadium species observed by EPR in the supported HPA catalysts correspond to tetragonally distorted octahedral [VO] ${ }^{2+}$-centers. ${ }^{49}$ For such species it would be expected that $g_{\mathrm{z}}<g_{\mathrm{x}}=g_{\mathrm{y}}$ and $A_{\mathrm{z}}>A_{\mathrm{x}}=A_{\mathrm{y}}$. The A-values observed here were lower than otherwise observed for $\mathrm{V}_{2} \mathrm{O}_{5}$ species on different oxide supports. ${ }^{24,50-52}$ 


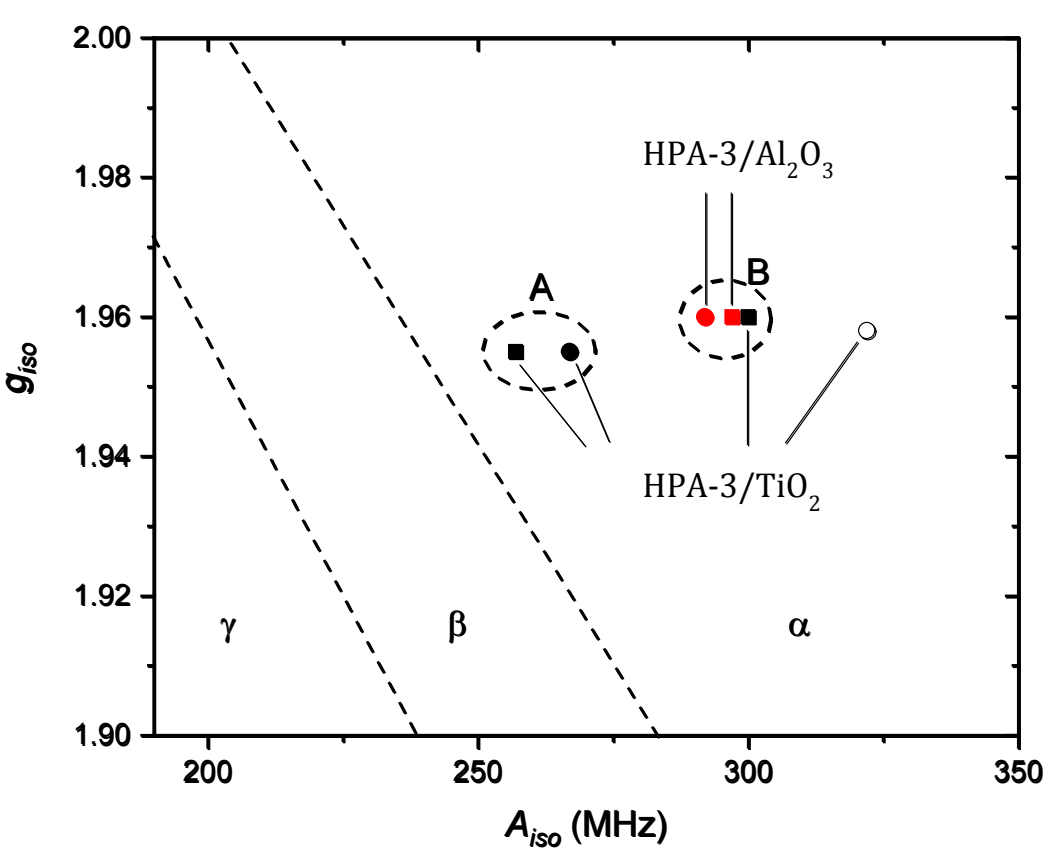

Figure 12: Isotropic spin Hamiltonian values for $\mathrm{HPA}-3 / \mathrm{Al}_{2} \mathrm{O}_{3}$ (red symbols) and $\mathrm{HPA}-3 / \mathrm{TiO}{ }_{2}$ (black symbols) plotted as in ${ }^{49}$. Square symbols represent the "reduced" samples and circles represent "oxidized" samples. The hollow circles are the $\mathrm{TiO}_{2}$ supported samples when saturated by water at room temperature.

The species of type A has very similar EPR parameters to the ones previously reported for Keggin polyoxometallates with one $\mathrm{V}^{4+}$ site..$^{53}\left(g_{\mathrm{x}}=g_{\mathrm{y}}=1.98, g_{\mathrm{z}}=1.94, A_{\mathrm{x}}=A_{\mathrm{y}}=156 \mathrm{MHz}, A_{\mathrm{z}}\right.$ $=453 \mathrm{MHz}$ ) The species of type $B$, on the other hand, have a different set of $g$ - and A-values and do not compare well with the literature of EPR on V in Keggin POMs. It is only present in very low percentages and one suggestion is that it corresponds to a minor amount of vanadium on the surface of a POM or in a partially broken down POM on the support. 50 It seems not to have any significant activity in the SCR reaction since it is the only species present in the catalytically inactive HPA-3/Al $\mathrm{O}_{3}$. The species of type $\mathrm{C}$ is dominant in the $\mathrm{TiO}_{2}$-supported samples and is much more interesting concerning catalytic activity since the observation of this species coincides with SCR activity and the total amount of this species changes with the identity of the reaction gases. The broad feature of the EPR signal of type $C$ is caused by magnetically interacting $V$ centers. The lack of features makes it impossible to identify structural details of these sites and the signal may be due to a combination of several types of sites. We can only comment that a strong interaction is compatible with several $\mathrm{V}^{4+}$ centers present in the same POM unit. It is very interesting that no species of either type $A$ or $C$ are observed on the $\mathrm{Al}_{2} \mathrm{O}_{3}$ support. We tentatively conclude that vanadium in $\mathrm{POM}$ units on the $\mathrm{Al}_{2} \mathrm{O}_{3}$ support are caught in oxidation state +5 and could not be reduced by $\mathrm{NO}+\mathrm{NH}_{3}$.

In the generally accepted mechanisms for the SCR reaction, vanadium is surrounded by oxygen atoms whereas $\mathrm{NO}$ and $\mathrm{NH}_{3}$ are in the second coordination sphere which is generally not detected by EPR spectroscopy. ${ }^{44,54}$ This is in accordance with our results since all observed spectra correspond to $\mathrm{V}$ coordinated to oxygen atoms. The lack of change in the EPR spectrum of the HPA-3/Al $\mathrm{O}_{3}$ catalyst during exposure to SCR gases suggested a difference in either the ability of vanadium in the POM to interact with the gases or a difference in the reduction potential due to the different POM-support interaction between $\mathrm{TiO}_{2}$ and $\mathrm{Al}_{2} \mathrm{O}_{3}$ supported catalysts. The difference in the response during interaction with $\mathrm{NH}_{3}$ further 
corroborated this observation (see Figures S8-S9) since the small amount of EPR alctivecle Online vanadium of type $\mathrm{B}$ in the $\mathrm{Al}_{2} \mathrm{O}_{3}$ supported catalyst was shown to be more easily reduced by $\mathrm{NH}_{3}$ than vanadium on $\mathrm{TiO}_{2}$ supported catalysts.

The vanadium in $\mathrm{TiO}_{2}$ supported catalysts, especially site $\mathrm{C}$, were much more responsive to oxidation by $\mathrm{NO} / \mathrm{O}_{2}$ and reduction by $\mathrm{NO} / \mathrm{NH}_{3}$ than the vanadium in the $\mathrm{Al}_{2} \mathrm{O}_{3}$ supported catalyst and this coincided with a higher activity in the SCR reaction. For each material a redoxwindow can be calculated based upon the EPR results: The weight of vanadium, which has changed oxidation state between steady-state at oxidizing and at reducing SCR conditions, divided by the total weight of the catalyst. The redox-window can be observed directly in the left graphs in Figure 10 as the magnitude of the gap between the upper and lower plateaus. The values are much higher in the catalysts that are active for the SCR reaction.

The other characterization methods applied in this work did not reveal a strong correlation between the respective responses and the SCR activity. We conclude that the changes in structural parameters within the POM units are relatively modest during reaction and that the acidity, porosity and surface area of the catalyst is not decisive here. On the other hand, the redox window observed during the in-situ EPR analysis was seen to be a very good descriptor for the SCR activity in these materials. 


\section{Conclusion}

Different supported vanadium-substituted HPA-n catalysts on $\mathrm{TiO}_{2}$ (anatase) have been prepared and examined for catalytic performance in the $\mathrm{NH}_{3}-\mathrm{SCR}$ reaction. Two competing effects were deduced within the HPA-n catalyst series; On the one hand, higher vanadium content increased the amount of redox-active sites, while on the other hand it also led to a lower thermal stability of the resulting HPA-n species due to an increasing basicity. HPA-3/TiO 2 showed the best compromise between these two effects, and $10 \mathrm{wt} \%$ HPA-3 loading was found to provide the highest SCR activity in the studied temperature range reaching nearly full $\mathrm{NO}$ conversion at $350^{\circ} \mathrm{C}$. HPA-support interaction as well as vanadium incorporation into the POM structure of the HPA increased the $\mathrm{NH}_{3}-\mathrm{SCR}$ activity when compared to reference catalysts with different combinations of vanadium-based catalysts on $\mathrm{TiO}_{2}$. Moreover, $\mathrm{TiO}_{2}$ clearly demonstrated to provide catalysts with superior activity.

Post-reaction analysis of the catalyst by TEM and XPS confirmed that the POM particles remained uniformly distributed and the HPA structure stable after reaction with an unchanged $\mathrm{V}^{4+}$ and $\mathrm{V}^{5+}$ distribution of 58 and $42 \%$. Finally, in-situ EPR studies showed that the $\mathrm{TiO}_{2}$ supported catalysts, including $\mathrm{HPA}-3 / \mathrm{TiO}_{2}$, were more responsive to oxidation and reduction by $\mathrm{NO} / \mathrm{O}_{2}$ and $\mathrm{NO} / \mathrm{NH}_{3}$ gases than the $\mathrm{Al}_{2} \mathrm{O}_{3}$ supported samples, which corresponded well to the fact that these samples were more catalytically active. Thus, it is reasonable to suggest that the redox-window can be used as measure of the SCR activity of the novel HPA catalysts. Due to the promising results obtained, a potassium tolerance study will be completed in the near future with the most promising catalyst. 


\section{Experimental details}

Materials and methods

All chemicals were commercially available and used without further purification. $\mathrm{V}_{2} \mathrm{O}_{5}(\geq 99.9 \%)$ was purchased from Alfa Aesar, $\mathrm{MoO}_{3}\left(\geq 99 \%\right.$ ) and $\mathrm{H}_{3} \mathrm{PO}_{4}$ (in water, $\geq 85 \%$ ) from Acros organics, $\mathrm{H}_{2} \mathrm{O}_{2}(30 \%$ aqueous solution) from Supelco $®$, ammonium meta-vanadate $(\geq 99 \%)$ and oxalic acid (99.9\%) from Sigma Aldrich. $\mathrm{TiO}_{2}$ (anatase, DT51-D crystal) was purchased from Cristal Global, $\mathrm{SiO}_{2}$ (Silica gel 60) from Fluka, Carbon Black (BlackPearl 1400) from Carbor, $\mathrm{ZrO}_{2}$ (NorPro) and $\mathrm{y}-\mathrm{Al}_{2} \mathrm{O}_{3}$ from Saint Gobain.

\section{Catalyst synthesis}

Vanadium-substituted HPA-n POMs, $\mathrm{H}_{3+\mathrm{n}} \mathrm{PV}_{\mathrm{n}} \mathrm{Mo}_{12-\mathrm{n}} \mathrm{O}_{40} \cdot \mathrm{xH}_{2} \mathrm{O}$ with $\mathrm{n}=0-6$, were synthesized according to the literature using a two-step method with non-substituted phosphomolybdic acid $\mathrm{H}_{3} \mathrm{PMo}_{12} \mathrm{O}_{40}$ precursor and the stable vanadium-precursor $\mathrm{H}_{9} \mathrm{PV}_{14} \mathrm{O}_{42}$. ${ }^{55} \mathrm{H}_{3} \mathrm{PMo}_{12} \mathrm{O}_{40}$ was obtained by heating $\mathrm{MoO}_{3}(0.620 \mathrm{~mol})$ in an aqueous solution of $\mathrm{H}_{3} \mathrm{PO}_{4}(0.051 \mathrm{~mol})$ followed by water removal under vacuum to give a crystalline solid. $\mathrm{H}_{9} \mathrm{PV}_{14} \mathrm{O}_{42}$ was synthesized by dissolving water-insoluble $\mathrm{V}_{2} \mathrm{O}_{5}$ (for HPA-5 synthesis exemplarily: $0.220 \mathrm{~mol}$ ) in cooled aqueous $\mathrm{H}_{2} \mathrm{O}_{2}$ (300 $\mathrm{ml}$ of $30 \mathrm{wt}$.\% in water) followed by adding $\mathrm{H}_{3} \mathrm{PO}_{4}(0.033 \mathrm{~mol}$ ) to stabilize the precursor. Subsequently, the aqueous vanadate precursor solution was added to the molybdate precursor under boiling conditions to yield the final HPA-n solution, where the water was removed under vacuum to give a crystalline solid (Yields $>95 \%$ ). The prepared materials were characterized by FTIR and compositional analysis using ICP-OES. The characterization data are included in the ESI (Figure S1, Table S1).

Supported HPA-n catalysts were prepared by suspending a known amount of dried support $\left(\mathrm{TiO}_{2}, \mathrm{SiO}_{2}\right.$, Carbon Black, $\mathrm{ZrO}_{2}$ or $\left.\mathrm{Y}-\mathrm{Al}_{2} \mathrm{O}_{3}\right)$ in aqueous solution of the corresponding HPA-n POM. Furthermore, a catalyst containing $\mathrm{V}_{2} \mathrm{O}_{5}$ and HPA-O $\left(\mathrm{H}_{3} \mathrm{PMo}_{12} \mathrm{O}_{40}\right)$ on $\mathrm{TiO}_{2}\left(\mathrm{~V}_{2} \mathrm{O}_{5}\right.$-HPA$0 / \mathrm{TiO}_{2}$ ) was prepared by wetness impregnation of HPA-0 and $2 \mathrm{M}$ vanadium(IV) oxalate solution on $\mathrm{TiO}_{2}$, followed by calcination at $450{ }^{\circ} \mathrm{C}$ prior to use. The vanadium oxalate solution for impregnation was prepared from ammonium meta-vanadate and oxalic acid in the molar ratio $1: 2$ at $70{ }^{\circ} \mathrm{C}$.

The metal loadings of $\mathrm{V}$ and Mo on the different supports were determined using ICP-OES. The characterization data are included in the ESI (Table S2). The impregnated catalysts were dried at $120^{\circ} \mathrm{C}$ for $12 \mathrm{~h}$ in an oven prior to characterization. Unless otherwise stated, all the catalysts were prepared with a POM loading of $15 \mathrm{wt} \%$.

\section{Catalyst characterization}

Inductive coupled plasma (ICP-OES)

The compositional analysis of HPA-n materials and the weight percentage of Mo and $\mathrm{V}$ contained in the impregnated catalysts were determined by ICP-OES. The measurements were carried out using a Perkin Elmer Plasma 400 by dissolving ca. $20 \mathrm{mg}$ of the HPA-n catalyst in $250 \mathrm{~mL}$ of double distilled water. For evaluation of the composition of the supported catalysts, sample preparation was done by carefully dissolving the catalysts in aqua regia (3:1 mixture of concentrated $\mathrm{HNO}_{3}$ and $\mathrm{HCl}$ ) in a microwave oven. For calibration, phosphorous, molybdenum and vanadium ICP-standard solutions $\left(1000 \mu \mathrm{g} \mathrm{mL}^{-1}\right)$ were used. 
Fourier-transformed infrared spectroscopy (FTIR)

Both freshly synthesized HPA-n materials and supported HPA-n catalysts were analysed by IR at ambient conditions using a Jasco FT/IR-4100 spectrometer equipped with a PIKE GladiATR ATR-accessory with a resolution of $4 \mathrm{~cm}^{-1}$. The FTIR spectra were recorded in the range between 4000 and $400 \mathrm{~cm}^{-1}$.

\section{Nitrogen physisortion}

$\mathrm{N}_{2}$ physisorption was carried out on a Quantachrome Autosorp $\mathrm{iQ}$ to determine specific surface area, pore volume and average pore diameter. The isotherms were measured at $77 \mathrm{~K}$ and 273 $\mathrm{K}$, respectively, with samples that were degassed for $12 \mathrm{~h}$ at $250{ }^{\circ} \mathrm{C}$ in vacuum prior to the adsorption measurement. The total surface area was calculated by the Brunauer-EmmettTeller (BET) method, the micro-pore volume and external surface area were calculated by the $\mathrm{t}$-plot method and the total pore volume was determined from the isotherm adsorption branch by a single point at around $\mathrm{p} / \mathrm{p}^{0}=0.95$.

\section{Ammonia temperature-programmed desorption $\left(\mathrm{NH}_{3}-\mathrm{TPD}\right)$}

The $\mathrm{NH}_{3}$-TPD measurements were carried out on a Micromeritics Autochem-II instrument. In a typical experiment, $100 \mathrm{mg}$ of dried sample was placed in a u-shaped quartz tube and pretreated in flowing $\mathrm{He}$ at $300{ }^{\circ} \mathrm{C}$. Afterwards, the temperature was lowered to $100{ }^{\circ} \mathrm{C}$ and the sample was treated with anhydrous $\mathrm{NH}_{3}$ gas (Air Liquide, $5 \% \mathrm{NH}_{3}$ in $\mathrm{He}$ ). Then, after $\mathrm{NH}_{3}$ adsorption, the sample was flushed with $\mathrm{He}(50 \mathrm{ml} / \mathrm{min})$ for $100 \mathrm{~min}$ at $100{ }^{\circ} \mathrm{C}$ and the $\mathrm{NH}_{3}-$ TPD was finally carried out by heating the sample from 100 to $300^{\circ} \mathrm{C}\left(10{ }^{\circ} \mathrm{C} / \mathrm{min}\right)$ in a flow of $\mathrm{He}(25 \mathrm{ml} / \mathrm{min})$. The $\mathrm{NH}_{3}$ concentration was measured using a TCD detector.

\section{$X$-ray photoelectron spectroscopy (XPS)}

XPS samples were measured on a ThermoScientific instrument using Al Ka X-rays (150 W). A constant analyser energy (CAE) mode was used to measure the survey spectra at a pass energy of $160 \mathrm{eV}$. An electron flood gun was used to achieve charge compensation. The software used for the deconvolution was a commercial Avantage 4.87.

Transmission electron microscopy (TEM)

TEM analysis was performed with a FEI Tecnai microscope operated at $200 \mathrm{kV}$. All samples were directly dispersed on holey or lacey carbon grids.

\section{Electron paramagnetic resonance (EPR) spectroscopy}

All EPR measurements were performed using an ER 4102ST cavity in a CW X-band Bruker EMX spectrometer. The power was set to $6.6 \mathrm{~mW}$, modulation amplitude was $5.2 \mathrm{G}$ and the modulation frequency was $100 \mathrm{KHz}$. Quantitative measurements were performed ex-situ using a $\mathrm{VOSO}_{4}$ standard diluted in $\mathrm{KSO}_{4}$. Approximately $20 \mathrm{mg}$ sample was transferred to a closed $4 \mathrm{~mm}$ suprasil quartz EPR tube and measured at ambient conditions. The measurement of each sample was done by addition of three scans in the range of $230-440 \mathrm{mT}$. In-situ measurements were performed by adding approximately $20 \mathrm{mg}$ sample to an open-ended quartz tube immobilized by two pieces of quartz wool resulting in a plug-flow reactor setup. The tube was placed in the cavity connected to a Bruker EMX VT heater permitting measurements in a temperature interval from room temperature to $290^{\circ} \mathrm{C}$. The gas flows were controlled by MKS mass-flow controllers. Unless otherwise stated, the total flow was 200 $\mathrm{mL} / \mathrm{min}$ in balance He and the concentrations of gases were $500 \mathrm{ppm}$ for $\mathrm{NO}, 550 \mathrm{ppm} \mathrm{NH}_{3}$, 2.3 vol\% for $\mathrm{H}_{2} \mathrm{O}$ and 4.5 vol\% $\mathrm{O}_{2}$, whenever the relevant gas was applied. Simulations and general data treatment was done in Matlab (2017R) using EasySpin 5.2.23. ${ }^{56}$ 
EPR spectra of all fresh samples and five standard samples containing $\mathrm{VOSO}_{4} \cdot 3 \mathrm{H}_{2} \mathrm{O}$ in $1 \mathrm{~K}_{10.133} \mathrm{SO}_{\text {ticle Online }}$ were collected ex-situ at room temperature. The intensity (the double integral) of the EPR spectrum of each fresh sample was then compared to a calibration curve based on the reference samples in order to determine the percentage of EPR active vanadium by weight. The in-situ measurements all started from a fresh catalyst sample and the first spectrum was therefore used as a reference point to calculate the time resolved intensity of each spectrum using the results of the ex-situ experiments. To account for the effect of temperature, a Boltzmann correction of the intensity for each individual spectrum was performed. Using this procedure the wt.\% of EPR active vanadium on each sample throughout an in-situ measurement was determined.

The ex-situ experiments of fresh samples showed that the $\mathrm{HPA}-3 / \mathrm{TiO}_{2}$ catalyst contained 0.18 \pm 0.01 wt. $\%$ EPR active $[\mathrm{VO}]^{2+}$, while $\mathrm{V}_{2} \mathrm{O}_{5}-\mathrm{HPA}-0 / \mathrm{TiO}_{2}$ contained $0.13 \pm 0.08 \mathrm{wt} . \%$ EPR active $[\mathrm{VO}]^{2+}$. HPA-3/ $/ \mathrm{Al}_{2} \mathrm{O}_{3}$ only gave a weak signal but it was estimated that it contained less than 0.05 wt. $\%$ EPR active [VO] ${ }^{2+}$. These amounts corresponded to 11,8 and $4 \%$ of the total $\mathrm{V}$ measured by ICP being EPR active for the catalysts. The quantification results are collected in Table 2 and in the ESI (Figure S2).

\section{Catalytic experiments}

The SCR activity measurements were carried out in a fixed-bed reactor loaded with $50 \mathrm{mg}$ of fractioned catalyst (180-300 $\mu \mathrm{m})$ and $\mathrm{SiO}_{2}$ as diluting agent $(300 \mathrm{mg})$ at atmospheric pressure. The reactant gas composition was adjusted to $1000 \mathrm{ppm} \mathrm{NO}, 1100 \mathrm{ppm} \mathrm{NH} \mathrm{NH}_{3}, 4.5 \mathrm{vol}_{\%} \mathrm{O}_{2}, 2.3$ vol\% $\mathrm{H}_{2} \mathrm{O}$ using Bronkhorst EL-Flow F-201C/D mass-flow controllers. The total gas flow was maintained at $512 \mathrm{~mL} / \mathrm{min}$. $\mathrm{NO}$ and $\mathrm{NH}_{3}$ concentrations were continuously monitored by a Thermo Electron Model $1 \mathrm{C}$ chemiluminescent $\mathrm{NH}_{3}-\mathrm{NO}_{x}$ gas analyzer. The temperature was increased stepwise from 200 to $350{ }^{\circ} \mathrm{C}$ during the activity measurements, and the SCR activity determined after steady-state was obtained at the desired temperature.

\section{Acknowledgements}

$\mathrm{AB}$ and JA thank the Erlangen Cluster of Excellence "Engineering of Advanced Materials" (www.eam.fau.de) for financial support. Additionally, we thank Simone Zacho (DTU) for performing TEM measurements.

\section{References}

1. Ilas, A.; Ralon, P.; Rodriguez, A.; Taylor, M., Renewable Power Generation Costs in 2017. International Renewable Energy Agency 2018.

2. Lüdge, S., The value of flexibility for fossil-fired power plants under the conditions of the Strommark 2.0. VGB PowerTech Journal 2017, 3, 212-214.

3. Agbor, E.; Zhang, X.; Kumar, A., A review of biomass co-firing in North America. Renewable and Sustainable Energy Reviews 2014, 40, 930-943.

4. Khorshidi, Z.; Ho, M. T.; Wiley, D. E., Techno-Economic Study of Biomass Co-Firing with and without CO2 Capture in an Australian Black Coal-Fired Power Plant. Energy Procedia 2013, 37, 6035-6042.

5. Nuamah, A.; Malmgren, A.; Riley, G.; Lester, E., 5.05 - Biomass Co-Firing. In Comprehensive Renewable Energy, Sayigh, A., Ed. Elsevier: Oxford, 2012; pp 55-73.

6. Mann, M.; Spath, P., A life cycle assessment of biomass cofiring in a coal-fired power plant. Clean Products and Processes 2001, 3 (2), 81-91. 
7. Kadiyala, A.; Kommalapati, R.; Huque, Z., Evaluation of the Life Cycle Greenhouse Gas Emission'sicle Online from Different Biomass Feedstock Electricity Generation Systems. Sustainability 2016, 8 (11), 1181.

8. Bjerg, J.; Aden, R.; Ogand, J. A.; Arrieta, J. A.; Hahlbrock, A.; Holmquist, L.; Kellberg, C.; KIp, W. N.; Koch, J.; Langnickel, U.; Nielsen, C.; Rising, A.; Rizkova, M.; Rookmaaker, J.; Ryckmans, Y.; Ryymin, R.; Shier, C.; Sochr, D.; Tatar, T.; Tolley, A., Biomass 2020: Opportuniies, Challenges and Solutions. Eurelectric 2001, 72.

9. Livingston, W. R., The status of large scale biomass firing: The milling and combustion of biomass materials in large pulverised coal boilers. IEA Bioenergy: Paris, 2016.

10. Forzatti, P., Present status and perspectives in de-NOx SCR catalysis. Applied Catalysis A: General 2001, 222 (1), 221-236.

11. Jensen-holm, H.; Lindenhoff, P.; Safronov, S., SCR Design Issues in Reduction of NOx Emissions from Thermal Power Plants. Haldor Topsøe A/S: Kongens Lyngby, Denmark 2007.

12. Clery, D. S.; Mason, P. E.; Rayner, C. M.; Jones, J. M., The effects of an additive on the release of potassium in biomass combustion. Fuel 2018, 214, 647-655.

13. Wieck-Hansen, K.; Overgaard, P.; Larsen, O. H., Cofiring coal and straw in a 150 MWe power boiler experiences. Biomass and Bioenergy 2000, 19 (6), 395-409.

14. Baxter, L., Biomass Impacts on SCR Catalyst Performance. IEA Task 32 Bioenergy Report 2005, IEA Bioenergy: Paris, France.

15. Lisi, L.; Lasorella, G.; Malloggi, S.; Russo, G., Single and combined deactivating effect of alkali metals and $\mathrm{HCl}$ on commercial SCR catalysts. Applied Catalysis B: Environmental 2004, 50 (4), 251-258.

16. Kern, P.; Klimczak, M.; Heinzelmann, T.; Lucas, M.; Claus, P., High-throughput study of the effects of inorganic additives and poisons on NH3-SCR catalysts. Part II: Fe-zeolite catalysts. Applied Catalysis B: Environmental 2010, 95 (1), 48-56.

17. Zheng, Y.; Jensen, A. D.; Johnsson, J. E.; Thøgersen, J. R., Deactivation of V2O5-WO3-TiO2 SCR catalyst at biomass fired power plants: Elucidation of mechanisms by lab- and pilot-scale experiments. Applied Catalysis B: Environmental 2008, 83 (3), 186-194.

18. Wu, H.; Bashir, M. S.; Jensen, P. A.; Sander, B.; Glarborg, P., Impact of coal fly ash addition on ash transformation and deposition in a full-scale wood suspension-firing boiler. Fuel 2013, 113, 632-643.

19. Jensen-holm, H.; Castellino, F.; White, T. N., SCR DeNOx catalyst considerations when using biomass in power generation. In Power Plant Air Pollutant Control "MEGA" Symposium, 2012; Vol. 1-27.

20. Kristensen, S. B. deNOx Catalysts for Biomass Combustion. Technical University of Denmark, Kongens Lyngby, Denmark, 2013.

21. Schill, L.; Fehrmann, R., Strategies of Coping with Deactivation of NH3-SCR Catalysts Due to Biomass Firing. Catalysts 2018, 8 (4), 135.

22. Olsen, B. J.; Kügler, F.; Castellino, F.; Schill, L.; Fehrmann, R.; Jensen, A. D., Deactivation of SCR Catalysts by Potassium: A Study of Potential Alkali Barrier Materials. VGB PowerTech Journal 2017.

23. Putluru, S. S. R.; Jensen, A. D.; Riisager, A.; Fehrmann, R., Heteropoly acid promoted V2O5/TiO2 catalysts for NO abatement with ammonia in alkali containing flue gases. Catalysis Science \& Technology 2011, 1 (4), 631-637.

24. Putluru, S. S. R.; Schill, L.; Gardini, D.; Mossin, S.; Wagner, J. B.; Jensen, A. D.; Fehrmann, R., Superior DeNOxactivity of V2O5-WO3/TiO2 catalysts prepared by deposition-precipitation method. Journal of Materials Science 2014, 49 (7), 2705-2713.

25. Ammam, M., Polyoxometalates: formation, structures, principal properties, main deposition methods and application in sensing. Journal of Materials Chemistry A 2013, 1 (21), 6291-6312.

26. Lechner, M.; Guttel, R.; Streb, C., Challenges in polyoxometalate-mediated aerobic oxidation catalysis: catalyst development meets reactor design. Dalton transactions (Cambridge, England : 2003) 2016, 45 (42), 16716-16726. 
27. Wang, S.-S.; Yang, G.-Y., Recent Advances in Polyoxometalate-Catalyzed Reactions. Cherimicojple Online Reviews 2015, 115 (11), 4893-4962.

28. Patel, A.; Singh, S., A green and sustainable approach for esterification of glycerol using 12tungstophosphoric acid anchored to different supports: Kinetics and effect of support. Fuel 2014, 118, 358-364.

29. Rafiee, E.; Eavani, S., A new organic-inorganic hybrid ionic liquid polyoxometalate for biodiesel production. Journal of Molecular Liquids 2014, 199, 96-101.

30. Patel, A.; Narkhede, N., 12-Tungstophosphoric Acid Anchored to Zeolite HB: Synthesis, Characterization, and Biodiesel Production by Esterification of Oleic Acid with Methanol. Energy \& Fuels 2012, 26 (9), 6025-6032.

31. Albert, J.; Mendt, M.; Mozer, M.; Voß, D., Explaining the role of vanadium in homogeneous glucose transformation reactions using NMR and EPR spectroscopy. Applied Catalysis A: General 2019, 570, 262-270.

32. Ren, Y.; Yue, B.; Gu, M.; He, H., Progress of the Application of Mesoporous Silica-Supported Heteropolyacids in Heterogeneous Catalysis and Preparation of Nanostructured Metal Oxides. Materials 2010, 3 (2), 764.

33. Odyakov, V. F.; Zhizhina, E. G.; Rodikova, Y. A.; Gogin, L. L., Mo-V-Phosphoric Heteropoly Acids and Their Salts: Aqueous Solution Preparation - Challenges and Perspectives. European Journal of Inorganic Chemistry 2015, 2015 (22), 3618-3631.

34. Braun, P.; Gebhard, J.; Matysik, F.-M.; Rabl, H.-P., Potential Technical Approaches for Improving Low-Temperature NOx Conversion of Exhaust Aftertreatment Systems. Chemie Ingenieur Technik 2018, 90 (6), 762-773.

35. Goldbach, M.; Roppertz, A.; Langenfeld, P.; Wackerhagen, M.; Füger, S.; Kureti, S., Urea Decomposition in Selective Catalytic Reduction on V2O5/WO3/TiO2 Catalyst in Diesel Exhaust. Chemical Engineering \& Technology 2017, 40 (11), 2035-2043.

36. Marberger, A.; Elsener, M.; Ferri, D.; Kröcher, O., VOx Surface Coverage Optimization of V2O5/WO3-TiO2 SCR Catalysts by Variation of the V Loading and by Aging. Catalysts 2015, 5 (4), 1704.

37. Jung, Y.; Shin, Y. J.; Pyo, Y. D.; Cho, C. P.; Jang, J.; Kim, G., NOx and N2O emissions over a UreaSCR system containing both V2O5-WO3/TiO2 and Cu-zeolite catalysts in a diesel engine. Chemical Engineering Journal 2017, 326, 853-862.

38. Ai, C.; Reich, P.; Schreier, E.; Jerschkewitz, H. G.; Oehlmann, G., ChemInform Abstract: Thermische Eigenschaften von Heteropolysäuren des Typs $\mathrm{H} 3+n$ [PV n Mo 12-n O 40 ] $\times x H 2 O$ ( $\mathrm{n}: 0,1,2,3)$. 2. Mitt. Raman- und IR-spektroskopische Untersuchungen. Chemischer Informationsdienst 1985, 16.

39. Bardin, B. B.; Davis, R. J., Characterization of copper and vanadium containing heteropolyacid catalysts for oxidative dehydrogenation of propane. Applied Catalysis A: General 1999, 185 (2), 283-292.

40. Xiong, S.; Xiao, X.; Liao, Y.; Dang, H.; Shan, W.; Yang, S., Global Kinetic Study of NO Reduction by NH3 over V2O5-WO3/TiO2: Relationship between the SCR Performance and the Key Factors. Industrial \& Engineering Chemistry Research 2015, 54 (44), 11011-11023.

41. Hu, X.; Lu, Y.; Dai, F.; Liu, C.; Liu, Y., Host-guest synthesis and encapsulation of phosphotungstic acid in MIL-101 via "bottle around ship": An effective catalyst for oxidative desulfurization. Microporous and Mesoporous Materials 2013, 170, 36-44.

42. Nova, I.; Ciardelli, C.; Tronconi, E.; Chatterjee, D.; Bandl-Konrad, B., NH3-SCR of NO over a Vbased catalyst: Low-T redox kinetics with NH3 inhibition. AIChE Journal 2006, 52 (9), 3222-3233.

43. Wachs, I. E.; Deo, G.; Weckhuysen, B. M.; Andreini, A.; Vuurman, M. A.; Boer, M. d.; Amiridis, M. D., Selective Catalytic Reduction of NO with NH3over Supported Vanadia Catalysts. Journal of Catalysis 1996, 161 (1), 211-221.

44. Kamata, H.; Takahashi, K.; Ingemar Odenbrand, C. U., Kinetics of the Selective Reduction of NO with NH3 over a V2O5(WO3)/TiO2 Commercial SCR Catalyst. Journal of Catalysis 1999, 185 (1), 106-113. 
45. Yin, X.; Han, H.; Gunji, I.; Endou, A.; Cheettu Ammal, S. S.; Kubo, M.; Miyamoto, A. ViNHA3cle Online Adsorption on the Brönsted and Lewis Acid Sites of V205(010): A Periodic Density Functional Study. The Journal of Physical Chemistry B 1999, 103 (22), 4701-4706.

46. Ashraf, S.; Blackman, C. S.; Hyett, G.; Parkin, I. P., Aerosol assisted chemical vapour deposition of $\mathrm{MoO} 3$ and $\mathrm{MoO} 2$ thin films on glass from molybdenum polyoxometallate precursors; thermophoresis and gas phase nanoparticle formation. Journal of Materials Chemistry 2006, 16 (35), 3575-3582.

47. Hartung, S.; Bucher, N.; Chen, H.-Y.; Al-Oweini, R.; Sreejith, S.; Borah, P.; Yanli, Z.; Kortz, U.; Stimming, U.; Hoster, H. E.; Srinivasan, M., Vanadium-based polyoxometalate as new material for sodium-ion battery anodes. Journal of Power Sources 2015, 288, 270-277.

48. Che, M.; Canosa, B.; Gonzalez-Elipe, A. R., Use of carbon monoxide and third-derivative EPR spectra to probe the coordination of surface vanadium(4+) ions on reduced vanadium pentoxide (V2O5)/silicon dioxide catalysts. The Journal of Physical Chemistry 1986, 90 (4), 618-621.

49. Davidson, A.; Che, M., Temperature-induced diffusion of probe vanadium(IV) ions into the matrix of titanium dioxide as investigated by ESR techniques. The Journal of Physical Chemistry 1992, 96 (24), 9909-9915.

50. Brückner, A., In situ electron paramagnetic resonance: a unique tool for analyzing structurereactivity relationships in heterogeneous catalysis. Chemical Society Reviews 2010, 39 (12), 4673-4684.

51. Alemany, L. J.; Lietti, L.; Ferlazzo, N.; Forzatti, P.; Busca, G.; Giamello, E.; Bregani, F., Reactivity and Physicochemical Characterization of V2O5-WO3/TiO2 De-NOx Catalysts. Journal of Catalysis 1995, 155 (1), 117-130.

52. Bahranowski, K.; Serwicka, E. M., ESR study of vanadium-doped alumina- and titania-pillared montmorillonites. Colloids and Surfaces A: Physicochemical and Engineering Aspects 1993, 72, 153-160.

53. Nambu, J.-i.; Ueda, T.; Guo, S.-X.; Boas, J. F.; Bond, A. M., Detailed voltammetric and EPR study of protonation reactions accompanying the one-electron reduction of Keggin-type polyoxometalates, [XVVM11040]4- $(\mathrm{X}=\mathrm{P}, \mathrm{As} ; \mathrm{M}=\mathrm{Mo}, \mathrm{W})$ in acetonitrile. Dalton Transactions 2010, 39 (31), 7364-7373.

54. Arnarson, L.; Falsig, H.; Rasmussen, S. B.; Lauritsen, J. V.; Moses, P. G., The reaction mechanism for the SCR process on monomer V5+ sites and the effect of modified Brønsted acidity. Physical Chemistry Chemical Physics 2016, 18 (25), 17071-17080.

55. Albert, J.; Lüders, D.; Bösmann, A.; Guldi, D. M.; Wasserscheid, P., Spectroscopic and electrochemical characterization of heteropoly acids for their optimized application in selective biomass oxidation to formic acid. Green Chemistry 2014, 16 (1), 226-237.

56. Stoll, S.; Schweiger, A., EasySpin, a comprehensive software package for spectral simulation and analysis in EPR. Journal of Magnetic Resonance 2006, 178 (1), 42-55. 